\title{
Assessment of Hydrochemistry, Facies Type and Processes Contributing the Major Ions to the Groundwater of Ajakanga Area, Ibadan, South Western Nigeria
}

\author{
Roland Anthony Isibor ${ }^{1}$ and Joseph Ayofe Aderogbin ${ }^{2}$ \\ ${ }^{1-2}$ Department of Earth Sciences \\ Faculty of Natural Sciences \\ Ajayi Crowther University \\ Oyo, Oyo state \\ Nigeria
}

\begin{abstract}
Resulting from insufficient supply of potable water and risk of possible contamination from anthropogenic sources, 14 samples were collected from wells at Ajakanga and environs in Ibadan, Southwestern Nigeria, in order to determine the shallow groundwater quality and desirability for drinking purposes. Physical parameters such as $\mathrm{pH}, \mathrm{EC}$, and TDS were measured at site using a combined $E C, T D S$ and $\mathrm{pH}$ meter. Major ions analyzed included $\mathrm{Na}^{+}, \mathrm{Ca}^{2+}, \mathrm{Mg}^{2+}, \mathrm{K}^{+}, \mathrm{NO}_{3}^{-}, \mathrm{Cl}^{-} \mathrm{HCO}_{3}^{-}$and $\mathrm{SO}_{4}^{2-}$. The anions were measured using titrimetric method, and analyzed by Genesys 2.0 Spectrophotometer, while the cations were analyzed using the flame photometry method. The hydrochemical data were subjected to a series of statistical analysis and conventional graphical plots. Results showed that all the chemical parameters analyzed, excepting $\mathrm{Cl}^{-}$fall within the World Health Organization permissible limit for drinking water. The shallow groundwater is therefore fit for drinking purposes. Cations concentration in the water is in the order of $\mathrm{Ca}>\mathrm{Mg}>\mathrm{Na}>\mathrm{K}$, while for the major anion $\mathrm{HCO}_{3}>\mathrm{Cl}>\mathrm{SO}_{4}>\mathrm{NO}_{3}$. Scatter plots and Gibbs diagram showed that the cations were released into the water as a result of weathering of the underlying basement rocks. Trilinear Piper diagram indicated two water facies in the area, with $\mathrm{CaHCO}_{3}$ water being dominant, while $\mathrm{CaMgHCO}_{3}$ is subordinate. Application of Chloro Alkaline Indices and the $\mathrm{Ca} / \mathrm{HCO}_{3}$ ratio indicated that reverse ion exchange reaction is responsible for the dominance of $\mathrm{Ca}^{2+}$ and $\mathrm{Mg}^{2+}$ in the waters.
\end{abstract}

Key Words: Hydrogeochemistry, Weathering, Groundwater, Water Facies, Reverse ion exchange.

\subsection{INTRODUCTION}

Surface waters are usually polluted and unsuitable for drinking and most domestic uses. Due to insufficient supply of potable water for drinking and other domestic uses as a result of gradual pollution of underground water system due to urbanization and agricultural and industrial activities in many developing countries [1,2], most people depend on groundwater for their daily needs [3] . It has estimated that more than 1.5 billion people globally rely on groundwater as their chief source of drinking water [4].

Ajakanga community, like other low population density settlements around Ibadan is currently experiencing influx of people. This arose from the need for affordable land for the building of residential houses outside the highly populated centers in Ibadan metropolis. This community depend largely on shallow groundwater in the area for most of their domestic activities, including drinking, cooking, and laundry due to total absence of public water supply. This is consequent upon the fact that such shallow groundwater systems, especially in the crystalline basement terrains, can be relatively easily tapped with minimal cost, and are a timely assured source compared to surface water development, especially in rural communities [5, 6].

However, groundwater contamination and the adverse health effects associated with it has become of concern globally. Poor quality of groundwater can result from several sources such as fertilizers, pesticides, poor sanitary practices and other anthropogenic sources. Open ground dumping is a common practice of waste disposal in Ajakanga community, Odo-Ona Kekere, Ibadan. This insanitary 
method of waste disposal allows contaminated liquid that has passed through the waste to infiltrate the ground water causing pollution of water resources available for domestic usage.

Consequently, it is important to ascertain the hydrogeochemistry of groundwater that is used for domestic and other purposes in order to assess the possible health risk it may pose. Generally, the chemical composition and quality of groundwater depend on interactions of several factors. A wide range of different elements can become dissolved in groundwater as a result of interactions with the atmosphere, the surficial environment, soil and bedrock. The interaction of these factors results in various water types [7].

Natural waters are commonly categorized by water types based on the relative percentages of major ions in the sample. The presence of any particular major ion in groundwater may not pose specific serious health risk to man, but understanding the type of water produced from an aquifer can be valuable in understanding some of the processes that affect the water quality conditions in groundwater.

Hydrogeochemistry has been employed in the identification of hydrochemical facies and to identify the origins and processes responsible for the chemical composition and suggest influences on groundwater chemistry $[8,9,10,11,12]$. Therefore, it is necessary to assess groundwater's suitability for drinking and domestic uses.

Consequently, this study is aimed at determining the quality of the shallow groundwater of Ajaganka area by analyzing the water samples for certain chemical parameters and comparing it with the World Health Organization (WHO) standard [13]. It also aimed to determine the water facies types and suggest the process contributing the major ions in the groundwater.

\subsection{Description of the Study Area}

The study area Ajakanga, Ibadan lies between N7 $7^{0} 17^{\prime} 30.5^{\prime \prime}, 3^{\circ} 49^{\prime} 29.15^{\prime \prime}$ and $7^{\circ} 19^{\prime} 59.0^{\prime \prime}, 3^{\circ} 50^{\prime} 38.8^{\prime \prime}$ on Ibadan sheet No 59 (Figure $1)$.

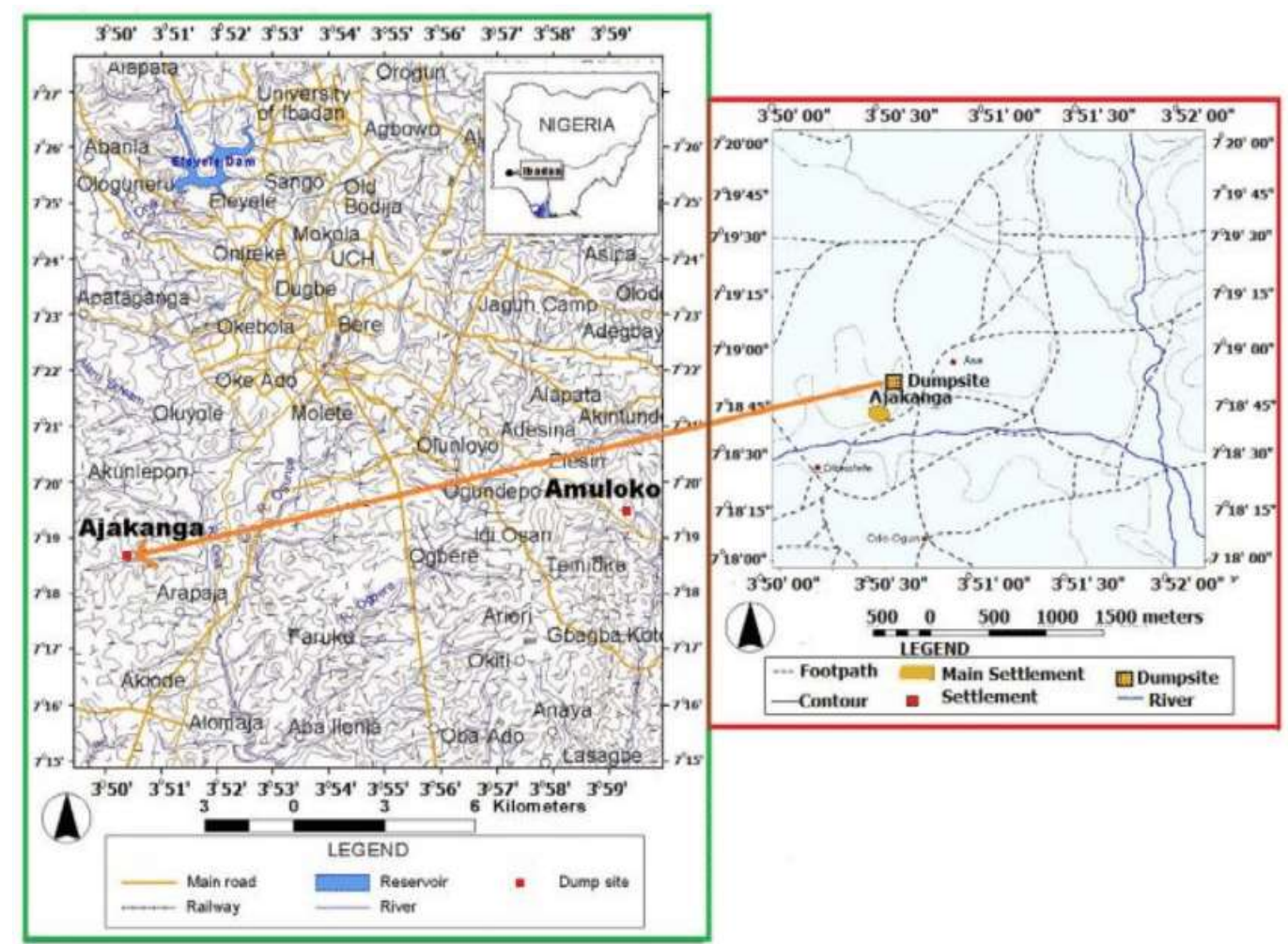

Figure 1: Map of Part of Ibadan Showing Ajakanga Area (Extracted from Nigeria Geological Survey Agency, Ibadan Sheet No.59, 1980)

Ibadan is a large urban city with heavy presence of commercial and industrial centers. The population grew from 175,000 in 1911 to 4 million in 2006 [14]. It is now one of the largest indigenous cities in tropical Africa. 
International Journal of Advances in Scientific Research and Engineering (ijasre), Vol 6 (4), April -2020

Ibadan can generally be divided into two distinct climatic seasons; the rainy and dry seasons [15]. Because of its latitudinal location, Ibadan enjoys the characteristics West African Monsoonal climate, marked by distinct seasonal shift in wind pattern. Between March, and October, the city is under the influence of the moist maritime south-west monsoon winds which blow inland from the Atlantic Ocean. This period is marked by constant rainfall and is referred to as the rainy season. The dry season occurs from November to February when the dust laden winds blow from the Sahara Desert. Within the two seasons, there are slight variations in intensity of the rain and the dryness [15]. The climate is tropical and the annual rainfall ranges between 1200-1600mm while the temperatures are relatively high $\left(20-36^{\circ} \mathrm{C}\right)$ with mean value of about $26^{\circ} \mathrm{C}$.

Ibadan shows great variation in vegetation. The natural vegetation of the study area is of the tropical rainforest, and is comprised of multitudes of evergreen trees and tall grasses typical of rainforest vegetation. Factors that govern vegetation here are the climate, relief, soil type and topography and the vegetation is thicker near the rivers and streams.

The general elevation of Ibadan is between $180 \mathrm{~m}$ and $210 \mathrm{~m}$ above the sea level. It covers essentially the areas between the hill bases, and its usually entrenched valley bottoms. Generally, the plains are smooth, with convexo-concave slope. The hills are the most striking features of Ibadan city, although they constitute less than 5\% of the total area. Two main types are recognized, the quartzite ridges and gneissic inselbergs; of these, the quartzite ridges are far the most impressive, widespread and best known. Common surface features found on the fresh rock outcrops include rock pits, quartz veins and exfoliation blocks. The surfaces are usually marked by various kinds of dissections and undulations and thick regolith which vary considerably in depth from place to place, even within short distances. In gneissic rock areas, the depth of weathering varies form nothing (fresh rock outcrops) to over 30m. The most important feature of this landform system is perhaps the conspicuous incision of the rivers into the flood plains or river bed. Generally, the relief of the area can be described as undulating.

The drainage pattern is mainly dendritic. The city of Ibadan is naturally drained by four rivers with many tributaries: Ona River in the North and West; Ogbere River towards the East; Ogunpa River flowing through the city and Kudeti River in the Central part of the metropolis. Ogunpa River is a third-order stream with a channel length of $12.76 \mathrm{~km}$ and a catchment area of $54.92 \mathrm{~km}^{2}$. Lake Eleyele is located at the northwestern part of the city, while the Osun River and the Asejire Lake bounds the city to the east.

\subsection{Geology and Hydrogeology}

The study area, Ajakanga, Ibadan lies within the Precambrian Basement Complex of South-western Nigeria, which is part of the Proterozoic mobile belts located between the West African and Congo Cratons. It lies within the region which have been subjected only to a thermos-tectonic event [16].

The rock suites of the basement complex include; Migmatite - Gneiss Quartzite Complex Suite; Metasedimentary and metavolcanic rocks (Schist Belts); Pan African Granitoids and the Undeformed acid and basic dykes [17, 18, 19].

The rock unit found in Ajakanga are; quartzite, banded gneiss, with pegmaties and quartzo-feldspartic intrusions (Figure. 2). 


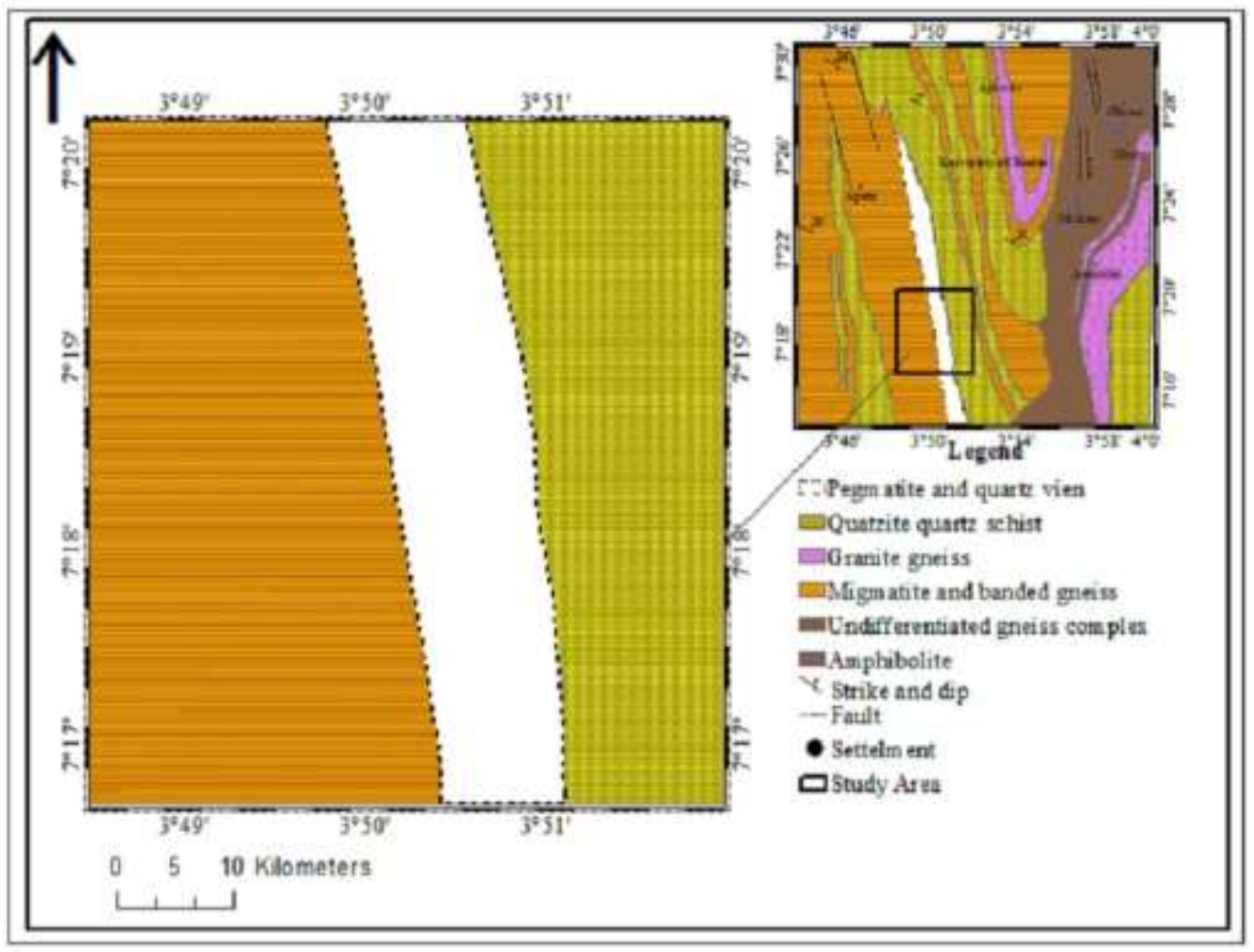

Figure 2: Geological map of Ajakanga Area, Ibadan. (Source: Nigerian Geological Survey Agency)

The quartzite are composed of interlocking, medium grained quartz. Areas where they occur are generally vegetated and covered with quartz fragments. The grains are mostly granoblastic in texture, and often whitish or greyish in colour. The dominant minerals are quartz, muscovite, iron oxide and biotite.

The banded gneiss occur close to the quartzites and are found as low-lying outcrops. The gneisses are usually strongly foliated, with a general strike of NNW-SSE direction. Usually, the bands are few centimeters in width, and the grains are predominantly medium sized. They are made up of minerals like quartz, biotite, and plagioclase feldspars.

Pegmatite and quartzo-feldspartic veins occur as concordant bodies in the banded gneiss. The coarse-grained pegmatites show a pale pink colour, while the quartz veins are white or grey.

Groundwater occurrence in much of southwestern Nigeria is essentially semi-confined to unconfined [20]. Due to the crystalline nature of the rock types in this region, the porosity and permeability necessary for the occurrence of large resources is lacking. However, appreciable porosity and permeability may develop through fracturing and weathering processes. Consequently, the weathered and fractured zones are the potential aquifers in basement terrains. Depth to water level rarely exceeds $24 \mathrm{~m}$, while most aquifers in this region occur within $40 \mathrm{~m}$ from the surface under unconfined conditions [20]. An average yield of 0.41/s and borehole depth of 40-80m is estimated for the crystalline basement rocks in Nigeria [21].

\subsection{MATERIALS AND METHODS}

\subsection{Sample Collection}

A total of 14 water samples were collected from wells within the study area, using new polythene bags, into clean new white plastic containers which were rinsed with the water sample to avoid contamination. The samples were adequately labelled and kept under cool temperature till they were sent to the laboratory for analysis. 
International Journal of Advances in Scientific Research and Engineering (ijasre), Vol 6 (4), April -2020

\subsection{Measurement of Physical Parameters}

Physical parameters such as $\mathrm{pH}$, electrical conductivity (EC), total dissolved solids (TDS) and temperature were measured at site during sampling operation. $\mathrm{pH}, \mathrm{EC}$ and TDS were measured with the use of a $\mathrm{pH}$ meter. The electrode was immersed in the water sample in a way that, the bulb at the tip of the electrode is completely covered by the sample and the reading shown on the screen was recorded.

\subsection{Measurement of Chemical Parameters}

Major ions analyses were carried out in the laboratory. Parameters analyzed included major cations such as $\mathrm{Na}, \mathrm{Ca}, \mathrm{Mg}, \mathrm{K}$, and anions$\mathrm{NO}_{3}{ }^{-}, \mathrm{Cl}^{-}, \mathrm{HCO}_{3}{ }^{-}$and $\mathrm{SO}_{4}{ }^{2-}$.

The anions including Nitrate, Chloride, and Sulphate were analysed by Spectrophotometer (Genesys20 Spectrometer). The parameter to be analysed for was selected from the test manager of the spectrophotometer. Two $10 \mathrm{ml}$ sample cells were filled with the sample to be tested, 1 pillow of test parameter was added to one of the sample in the sample cell and was shaken, and it was then allowed to stay for reaction time depending on the test parameter. The blank was then placed in the sample chamber to calibrate to zero, then the second sample cell was placed in the chamber, the concentration of the test parameter in $\mathrm{mg} / \mathrm{l}$ is then displayed on the spectrophotometer screen.

Cations like Sodium, Potassium, Calcium and Magnessium were analyzed by the Flame Photometry method. Sample was aspirated into the flame through an inlet hose, in which the Flame Photometer has been calibrated by series of known standard of the tested parameters, the concentration of the tested parameter is displayed on the screen. Flame photometry is a simple, relatively inexpensive method used for clinical, biological, and environmental analysis. The flame photometer used for this present work is Buck PFP-7 flame photometer.

Statistical analyses including descriptive statistics, factor analysis and principal component analysis were carried out using the SPSS 20 package.

\subsection{RESULTS AND DISCUSSIONS}

\subsection{Hydrogeochemical Characteristics and Groundwater Quality}

The coordinates of the location of the water samples is given in Table 1, while a summary of the physical and chemical parameters is given in Table 2 alongside the World Health Organization (WHO) standards. Table 3 showed the concentration of the ions in milliequivalent per litre.

Table 1: Location coordinates of the shallow groundwater samples

\begin{tabular}{|l|l|l|l|}
\hline $\begin{array}{l}\text { SAMPLE } \\
\text { LOCATION }\end{array}$ & LONGITUDE & LATITUDE & $\begin{array}{l}\text { ELEVATION } \\
(\mathbf{m})\end{array}$ \\
\hline $\mathbf{1}$ & $7^{\circ} 18^{\prime} 38.2^{\prime \prime}$ & $3^{\circ} 50^{\prime} 24.9^{\prime \prime}$ & 154 \\
\hline $\mathbf{2}$ & $7^{\circ} 18^{\prime} 46.6^{\prime \prime}$ & $3^{\circ} 50^{\prime} 30.4^{\prime \prime}$ & 139 \\
\hline $\mathbf{3}$ & $7^{\circ} 18^{\prime} 45.0^{\prime \prime}$ & $3^{\circ} 50^{\prime} 29.0^{\prime \prime}$ & 161 \\
\hline $\mathbf{4}$ & $7^{\circ} 18^{\prime} 42.2^{\prime \prime}$ & $3^{\circ} 50^{\prime} 32.3^{\prime \prime}$ & 137 \\
\hline $\mathbf{5}$ & $7^{\circ} 18^{\prime} 40.0^{\prime \prime}$ & $3^{\circ} 50^{\prime} 27.1^{\prime \prime}$ & 144 \\
\hline $\mathbf{6}$ & $7^{\circ} 18^{\prime} 55.5^{\prime \prime}$ & $3^{\circ} 50^{\prime} 38.8^{\prime \prime}$ & 157 \\
\hline $\mathbf{7}$ & $7^{\circ} 18^{\prime} 31.8^{\prime \prime}$ & $3^{\circ} 50^{\prime} 16.9^{\prime \prime}$ & 154 \\
\hline $\mathbf{8}$ & $7^{\circ} 19^{\prime} 10.6^{\prime \prime}$ & $3^{\circ} 50^{\prime} 50.5^{\prime \prime}$ & 177 \\
\hline $\mathbf{9}$ & $7^{\circ} 19^{\prime} 25.5^{\prime \prime}$ & $3^{\circ} 51^{\prime} 10.9$ & 168 \\
\hline $\mathbf{1 0}$ & $7^{\circ} 19^{\prime} 59.0^{\prime \prime}$ & $3^{\circ} 51^{\prime} 20.1^{\prime \prime}$ & 149 \\
\hline $\mathbf{1 1}$ & $7^{\circ} 18^{\prime} 14.2^{\prime \prime}$ & $3^{\circ} 49^{\prime} 51.0^{\prime \prime}$ & 148 \\
\hline $\mathbf{1 2}$ & $7^{\circ} 18^{\prime} 01.8^{\prime \prime}$ & $3^{\circ} 49^{\prime} 45.6^{\prime \prime}$ & 165 \\
\hline $\mathbf{1 3}$ & $7^{\circ} 17^{\prime} 30.5^{\prime \prime}$ & $3^{\circ} 49^{\prime} 22.6^{\prime \prime}$ & 178 \\
\hline $\mathbf{1 4}$ & $7^{\circ} 17^{\prime} 48.0^{\prime \prime}$ & $3^{\circ} 49^{\prime} 15.7^{\prime \prime}$ & 172 \\
\hline
\end{tabular}


International Journal of Advances in Scientific Research and Engineering (ijasre), Vol 6 (4), April -2020

Table 2: Comparison of physical and chemical parameters measured in the water samples with WHO 2008 International standard for portable drinking water.

\begin{tabular}{|l|l|l|l|l|}
\hline PARAMETERS & RANGE & MEAN & $\begin{array}{l}\text { STANDARD } \\
\text { DEVIATION }\end{array}$ & WHO STANDARD \\
\hline pH & $6.55-7.38$ & 7.14 & 0.26 & $6.5-8.5$ \\
\hline TDS(mg/L) & $220-1190$ & 375 & 266.01 & 1000 \\
\hline EC $(\boldsymbol{\mu s} / \mathbf{c m})$ & $200-1780$ & 560 & 398.52 & 1500 \\
\hline Total Hardness (mg/L) & $52-700$ & 191.43 & 164.13 & 500 \\
\hline Turbidity(FTU) & $0.09-35.65$ & 3.22 & 9.46 & \\
\hline Total Alkalinity (mg/L)CaCO $\mathbf{3})$ & $48-670$ & 190.29 & 156.67 & - \\
\hline Chloride $(\mathbf{m g} / \mathbf{L})$ & $17.93-298.46$ & 68.21 & 81.62 & 250 \\
\hline Bicarbonate(mg/L) & $66-630$ & 217.86 & 160.14 & - \\
\hline Nitrate $(\mathbf{m g} / \mathbf{L})$ & $0.12-2.12$ & 0.29 & 0.53 & 50 \\
\hline Sulphate $(\mathbf{m g} / \mathbf{L})$ & $2-68$ & 11.86 & 16.80 & 250 \\
\hline Calcium $(\mathbf{m g} / \mathbf{L})$ & $16.01-110.43$ & 39.66 & 30.58 & 250 \\
\hline Magnesium $(\mathbf{m g} / \mathbf{L})$ & $3.43-123.55$ & 26.39 & 29.82 & 150 \\
\hline Sodium $(\mathbf{m g} / \mathbf{L})$ & $5.88-58.31$ & 13.90 & 13.19 & 200 \\
\hline Potassium $(\mathbf{m g} / \mathbf{L})$ & $0.02-27.24$ & 6.02 & 6.98 & 50 \\
\hline
\end{tabular}

Table 3: Concentrations of major ions in milliequivalent per liter

\begin{tabular}{|l|l|l|l|l|l|l|l|l|}
\hline Sample location & Ca & Na & K & Mg & HCO3 & Cl & SO4 & NO3 \\
\hline $\mathbf{1}$ & 5.361 & 2.535 & 0.698 & 5.084 & 10.328 & 8.527 & 1.417 & 2.12 \\
\hline $\mathbf{2}$ & 1.040 & 0.793 & 0.287 & 1.930 & 3.607 & 4.069 & 0.333 & 0.16 \\
\hline $\mathbf{3}$ & 0.960 & 0.256 & 0.052 & 0.188 & 1.082 & 0.512 & 0.208 & 0.12 \\
\hline $\mathbf{4}$ & 5.522 & 0.499 & 0.184 & 0.988 & 5.770 & 4.155 & 0.375 & 0.18 \\
\hline $\mathbf{5}$ & 1.920 & 0.281 & 0.109 & 0.471 & 2.295 & 2.505 & 0.125 & 0.16 \\
\hline $\mathbf{6}$ & 1.920 & 0.512 & 0.134 & 1.130 & 3.148 & 0.569 & 0.167 & 0.19 \\
\hline $\mathbf{7}$ & 2.001 & 0.667 & 0.231 & 0.753 & 2.689 & 2.789 & 0.083 & 0.15 \\
\hline $\mathbf{8}$ & 1.760 & 0.487 & 0.170 & 0.753 & 2.557 & 0.683 & 0.083 & 0.16 \\
\hline $\mathbf{9}$ & 1.040 & 0.441 & 0.105 & 0.800 & 1.967 & 0.455 & 0.083 & 0.12 \\
\hline $\mathbf{1 0}$ & 0.801 & 0.399 & 0.053 & 0.141 & 7.869 & 0.968 & 0.042 & 0.11 \\
\hline $\mathbf{1 1}$ & 0.801 & 0.361 & 0.134 & 0.753 & 1.803 & 0.569 & 0.167 & 0.16 \\
\hline $\mathbf{1 2}$ & 1.281 & 0.364 & 0.103 & 0.659 & 1.934 & 0.569 & 0.083 & 0.14 \\
\hline $\mathbf{1 3}$ & 1.440 & 0.455 & 0.157 & 0.800 & 2.328 & 0.455 & 0.125 & 0.12 \\
\hline $\mathbf{1 4}$ & 1.920 & 0.411 & 0.134 & 0.753 & 2.623 & 0.455 & 0.167 & 0.15 \\
\hline Mean & 1.983 & 0.604 & 0.182 & 1.086 & 3.571 & 1.949 & $0 . .247$ & 0.289 \\
\hline
\end{tabular}

Statistical analyses of the results (Table 2) of the chemical composition of the groundwater samples showed that the $\mathrm{pH}$ ranged from 6.55 to 7.43 (Figure 3) with a mean value 7.15. Samples from location 1, 2 and 5 which represent $21.4 \%$ of the sample population have values below 7.0 indicating mildly acidic water, while the remaining $78.6 \%$ of the sampled groundwater were mildly alkaline. These $\mathrm{pH}$ values fall within the WHO standard for domestic water of 6.55 to 8.50 .

The electrical conductivity for the samples range from 200.00 to 1780.00 (Figure 4) with a mean value of 560.00. Based on WHO guidelines, EC permissible limit is 1500. Samples from location 1 with a value of 1780, however, exceeded this limit and is therefore unfit for drinking, while the remaining samples have values within the WHO standard and may be used for drinking purposes. Water that has relatively high EC can corrode iron and steel because specific conductance reflects activity of electrically charged ions, it follows that the higher the conductivity, the greater will be the potential for electrochemical action.

The TDS has a minimum value of 135.0 with a maximum value of 1190.0 (Figure 5), and a mean value of 375.0. [22] on the basis of TDS classified groundwater suitable for drinking and irrigation as follows; TDS up to 500mg/L (desirable for drinking); 500 - 
International Journal of Advances in Scientific Research and Engineering (ijasre), Vol 6 (4), April -2020

$1000 \mathrm{mg} / \mathrm{L}$ (permissible for drinking) and up to 3000mg/L (useful for agricultural purposes). Only sample from location 1 which constitute $7.14 \%$ of the sampled population has a value $(1190 \mathrm{mg} / \mathrm{L})$ above the permissible drinking standard.

The Total Hardness of the samples ranged from 52 to 700 (Figure 6) with a mean of 191.43. Groundwater can be classified based on Total Hardness into soft $(0-60 \mathrm{TH})$, moderately hard (61 to $120 \mathrm{TH})$, hard (121 to $180 \mathrm{TH})$ and very hard (> 180 TH) [23]. B ased on this $7.14 \%$ of the groundwater in the area is soft, $28.57 \%$ moderately hard, $35.71 \%$ hard and 28.57 very hard.

The concentration of $\mathrm{Ca}^{2+}$ in the water ranged from 16.01 to $110.43(0.801-5.361 \mathrm{meq} / \mathrm{L})$ (Figure 7$)$ with a mean value of 39.66 $(1.983 \mathrm{meq} / \mathrm{L})$. Waters with less than $20 \mathrm{meq} / \mathrm{L}$ can be used for irrigation purposes [24]. The highest value for Ca in the sample waters is $5.361 \mathrm{meq} / \mathrm{L}$. Consequently, water from the area may be employed for irrigation purposes. $\mathrm{K}^{+}$concentration range from $2.03 \mathrm{mg} / \mathrm{L}$ to $27.24 \mathrm{mg} / \mathrm{L}$ with a mean of $7.11 \mathrm{mg} / \mathrm{L}$ (Figure 8 ).

$\mathrm{Na}^{+}$concentration ranged from 5.88 to $58.31 \mathrm{mg} / \mathrm{L}(0.256-2.535 \mathrm{meq} / \mathrm{L})$ (Figure 9) with a mean of $13.90 \mathrm{mg} / \mathrm{L}(0.604 \mathrm{meq} / \mathrm{L})$. Water containing less than $40 \mathrm{meq} / \mathrm{L}$ can generally be used for irrigation. Consequently, water from the area can be used for irrigation purposes, since the $\mathrm{Na}^{+}$values of all sample fall below 40meq/L. Possible sources of sodium in groundwater are weathered plagioclase feldspars, exchangeable sodium from clay and atmosphere dust washed away by rain.

$\mathrm{Mg}^{2+}$ concentration ranged from 3.43 to $123.55(0.141-5.084 \mathrm{meq} / \mathrm{L})$ (Figure 10$)$ with a mean value of $26.39\left(1.086 \mathrm{meq} / \mathrm{L}^{2}\right.$. $\mathrm{HCO}_{3}{ }^{-}$ concentration ranged from 66.00 to $630.00 \mathrm{mg} / \mathrm{L}$ (Figure 11) with a mean value of 217.86 . Bicarbonate is believed to enter the groundwater system through the uptake of carbon dioxide $\left(\mathrm{CO}_{2}\right)$ from gaseous soil zone or direct atmosphere. Because of this, shallow groundwater is expectedly high in bicarbonates. However, bicarbonate concentrations in crystalline ground waters decrease with depth.

The concentration of $\mathrm{Cl}^{-}$ranged from 15.94 to $298.46(0.455-8.527 \mathrm{meq} / \mathrm{L})$ (Figure 12) with a mean of 68.21 (1.949meqL) the maximum permissible limit for $\mathrm{Cl}^{-}$in irrigation water is $30 \mathrm{meqL}$. Accordingly, all samples collected from the area fall within the permissible limits and can be used for irrigation purposes. The concentration of $\mathrm{Cl}^{-}$in most of the sampled water fall within that expected from natural sources $(100 \mathrm{mg} / \mathrm{L})$. However, $\mathrm{Cl}^{-}$is higher than that expected from natural source in locations 1 , 2 and 4 . In these locations $\mathrm{Cl}^{-}$may have been contributed from anthropogenic sources. $\mathrm{SO}_{4}{ }^{2-}$ concentration ranged from 2.00 to 68.00 (Figure 13 ) with a mean concentration of 11.86 . In groundwater 10 to $15 \mathrm{mg} / \mathrm{L}$ concentration of $\mathrm{SO}_{4}{ }^{2+}$ is reasonable and acceptable as contribution from natural sources. This much concentration may not require any rich $\mathrm{SO}_{4}$ source. Interaction of rain water with ground surface is sufficient to explain this much concentration. Only in locations 1,2 and 4 does the concentration of $\mathrm{SO}_{4}$ exceed $15 \mathrm{mg} / \mathrm{L}$. The excess $\mathrm{SO}_{4}$ may have been contributed from the use of pesticides, fertilizers, organic matter and reduced sulfide minerals. $\mathrm{NO}_{3}{ }^{-}$concentration in the samples ranged from 0.11 to $2.12 \mathrm{mg} / \mathrm{L}$ (Figure 14) with a mean of $0.29 . \mathrm{NO}_{3}$ is the primary form of nitrogen. It is soluble in water and can easily pass through soil to the groundwater table.

Compared to the WHO standard maximum permissible level of 250 for $\mathrm{Cl}^{-}$, only water sample from location 1 , representing $7.14 \%$ of the sampled population exceeded these limits for $\mathrm{Cl}^{-}$rendering the water in that location undesirable for drinking. Concentrations of the major cations in the water showed that $\mathrm{Ca}^{2+}>\mathrm{Mg}^{2+}>\mathrm{Na}^{+}>\mathrm{K}^{+}$, while for the major anions $\mathrm{HCO}_{3}^{-}>\mathrm{Cl}^{-}>\mathrm{SO}^{2+}>\mathrm{NO}_{3}^{-}$. Excepting sample from location 1 showing higher concentration of $\mathrm{Cl}^{-}$than WHO (2008) maximum permissible limits, waters from all the other locations representing $92.86 \%$ of the sampled population can be used for drinking purposes. 
International Journal of Advances in Scientific Research and Engineering (ijasre), Vol 6 (4), April -2020

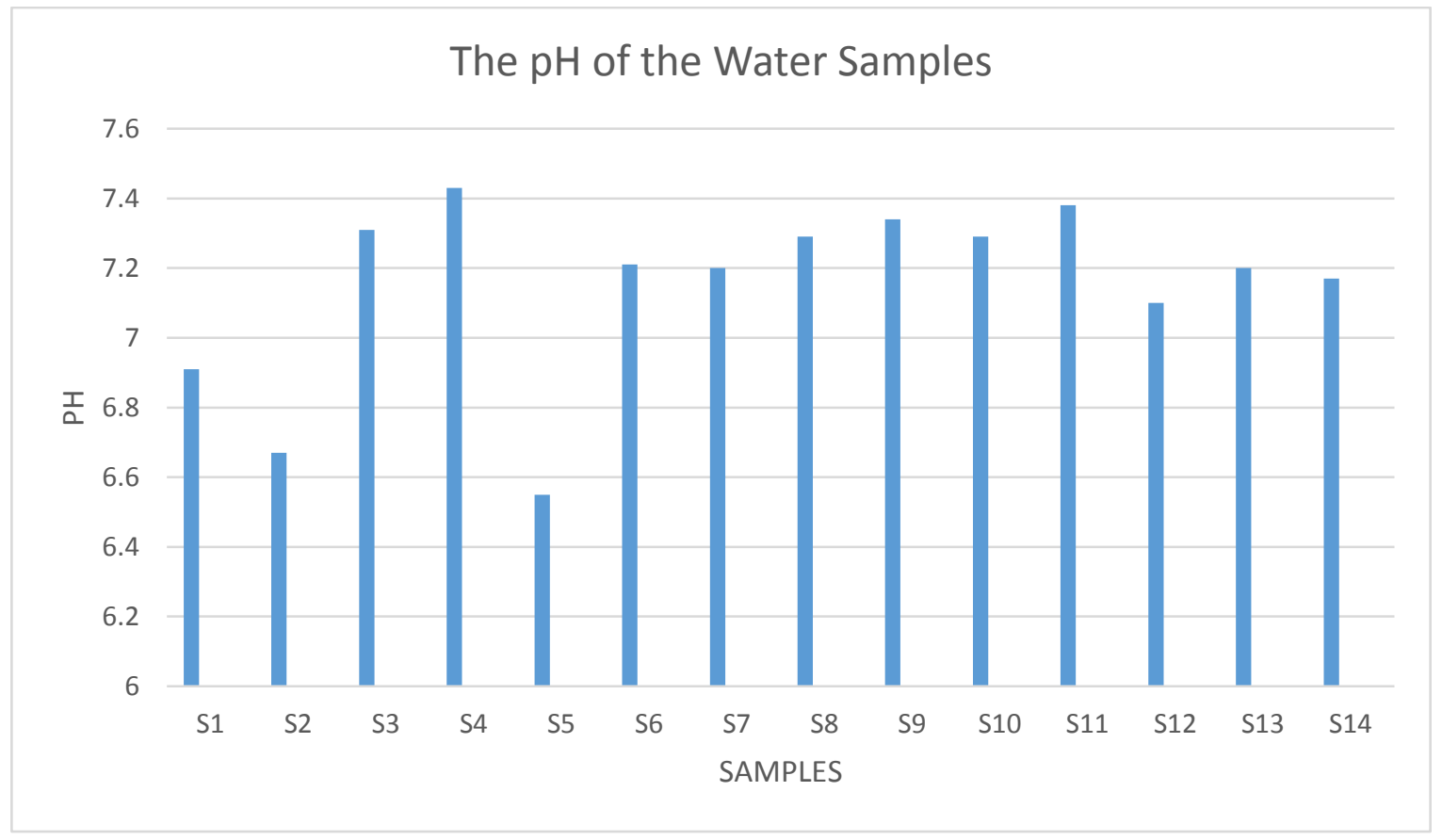

Figure 3: Chart showing the $\mathrm{pH}$ of the water samples

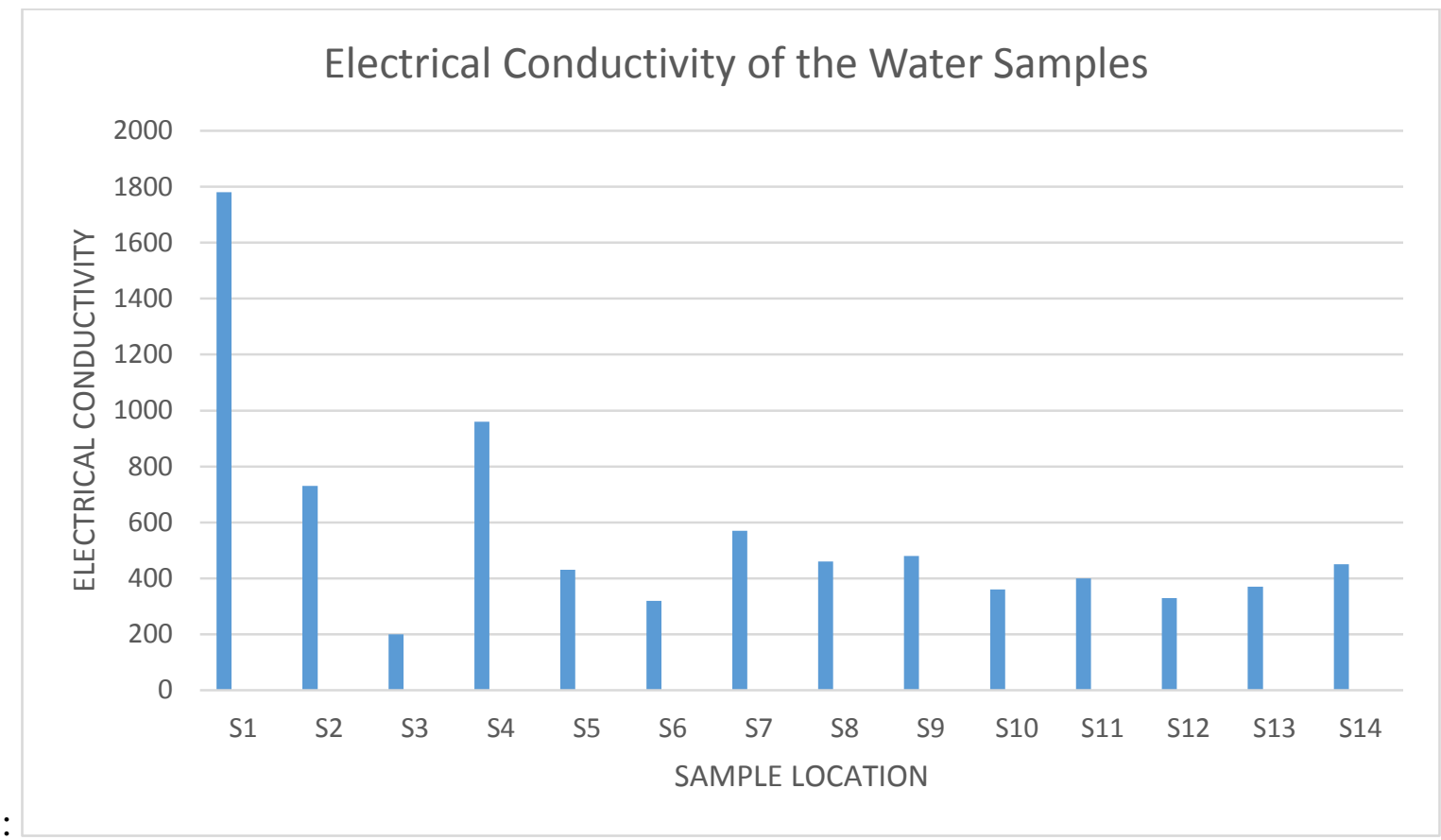

Figure 4: Chart showing the electrical conductivity of the water samples 
International Journal of Advances in Scientific Research and Engineering (ijasre), Vol 6 (4), April -2020

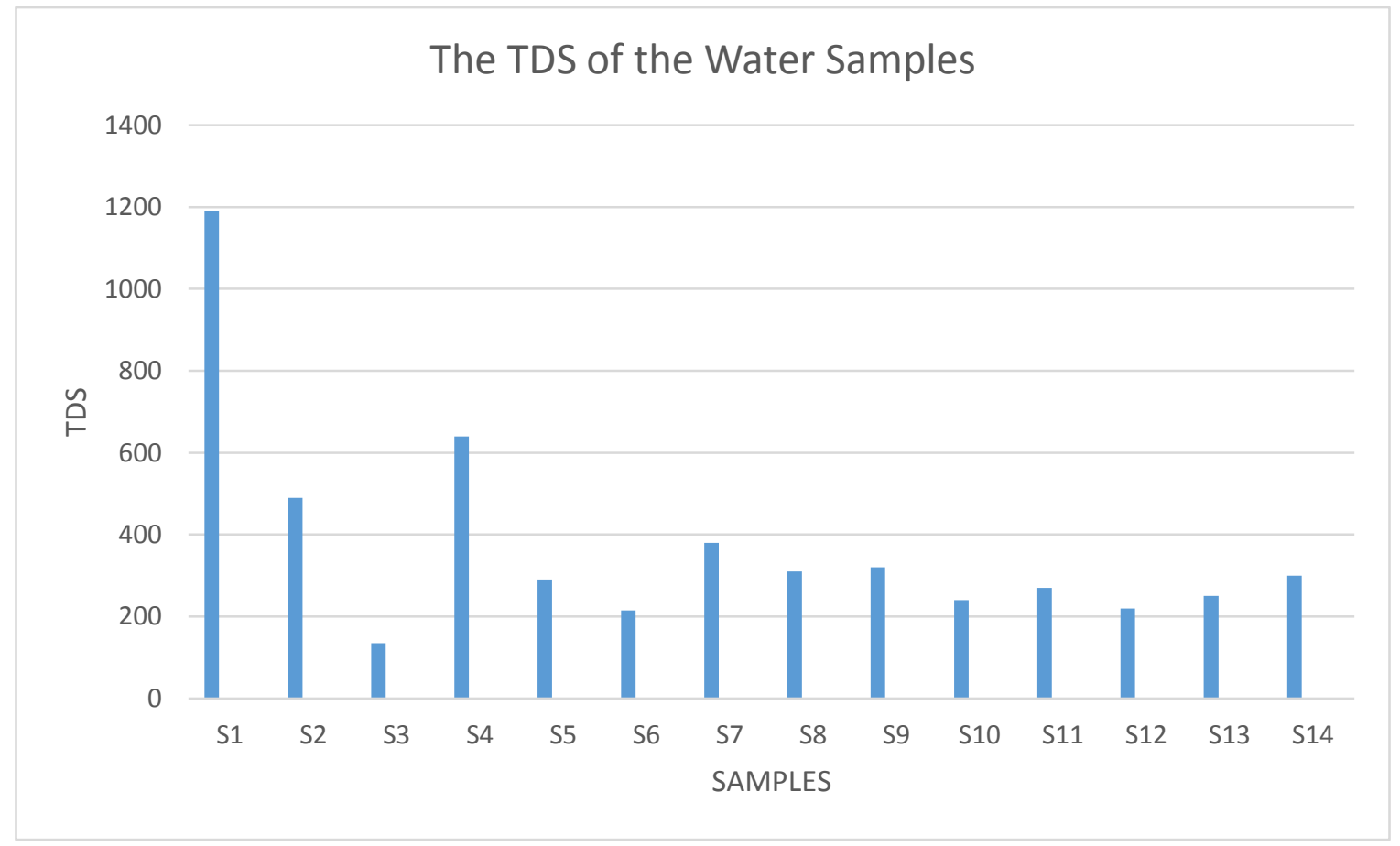

Figure 5: Chart showing the TDS of the water samples

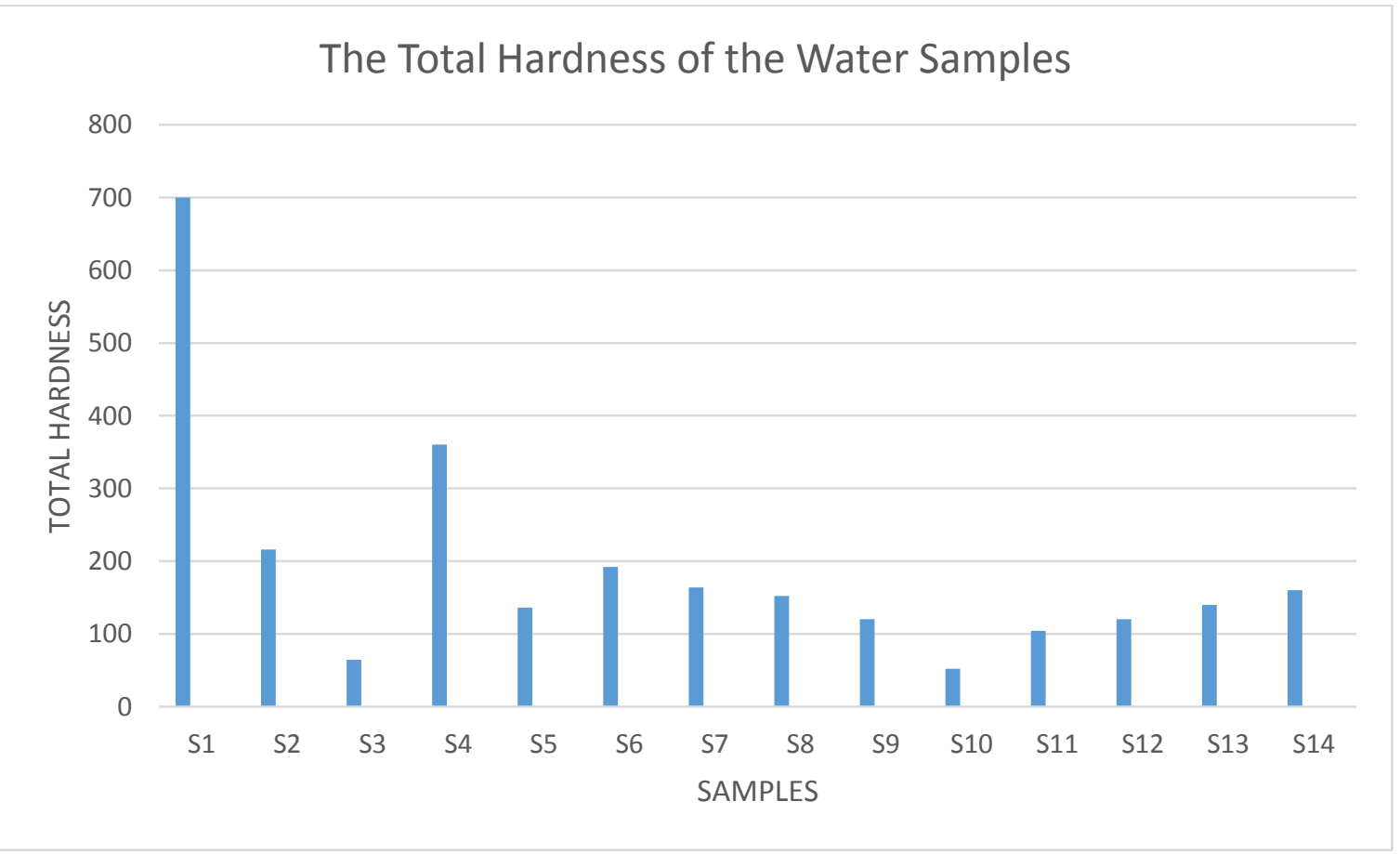

Figure 6: Chart showing the total hardness of the water samples 
International Journal of Advances in Scientific Research and Engineering (ijasre), Vol 6 (4), April -2020

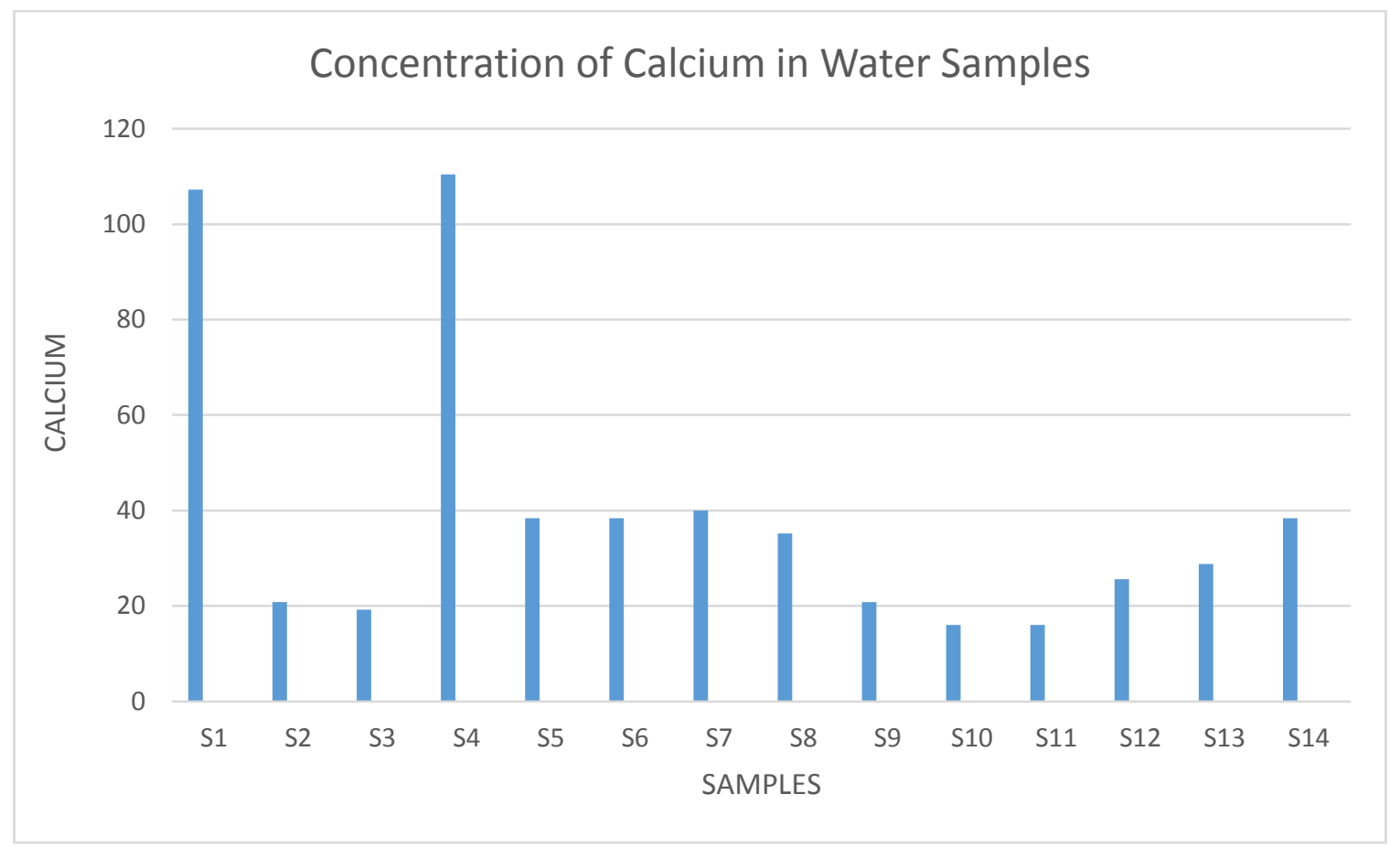

Figure 7: Chart showing concentration of calcium in water samples

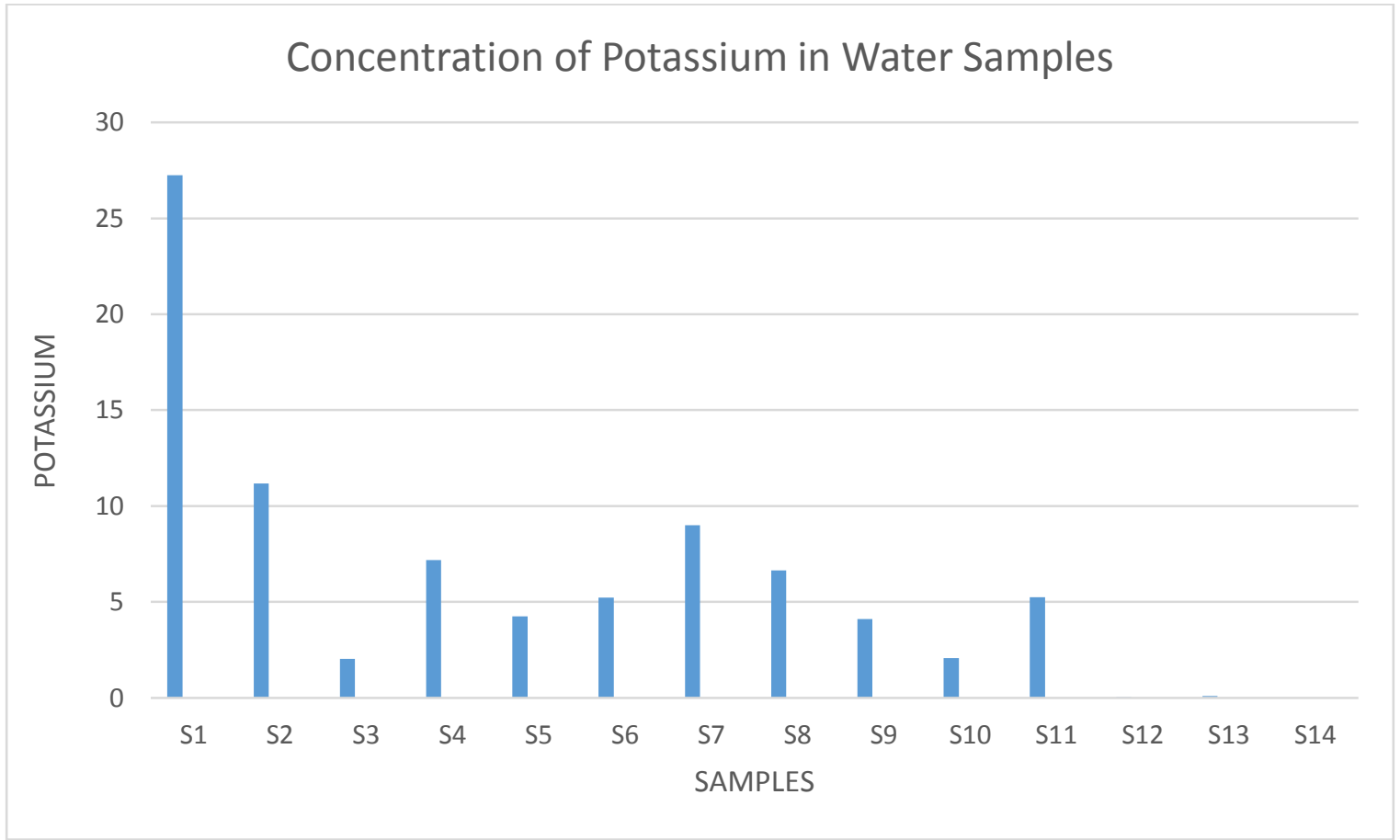

Figure 8: Chart showing concentration of potassium in water samples 
International Journal of Advances in Scientific Research and Engineering (ijasre), Vol 6 (4), April -2020

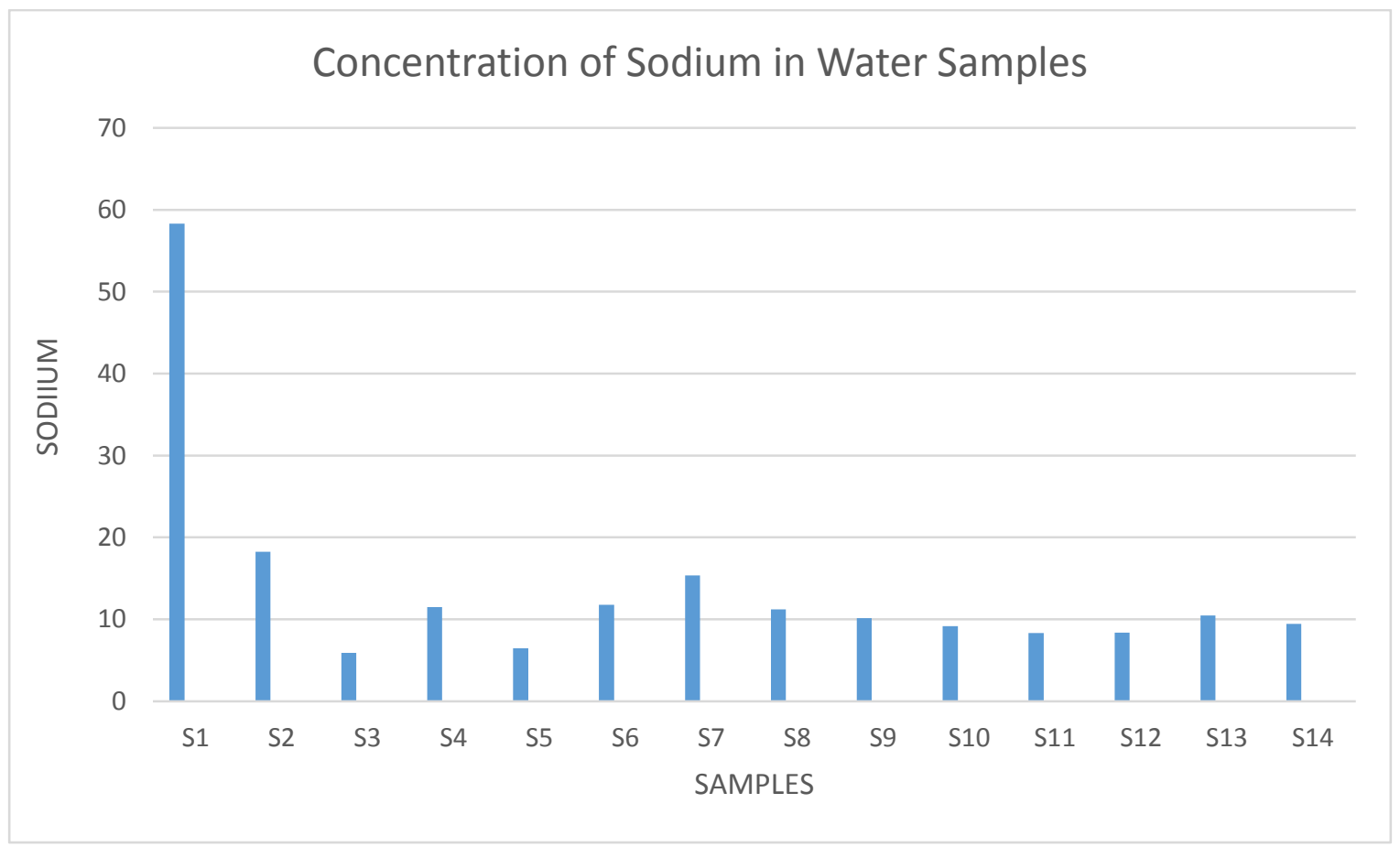

Figure 9: Chart showing concentration of sodium in water samples

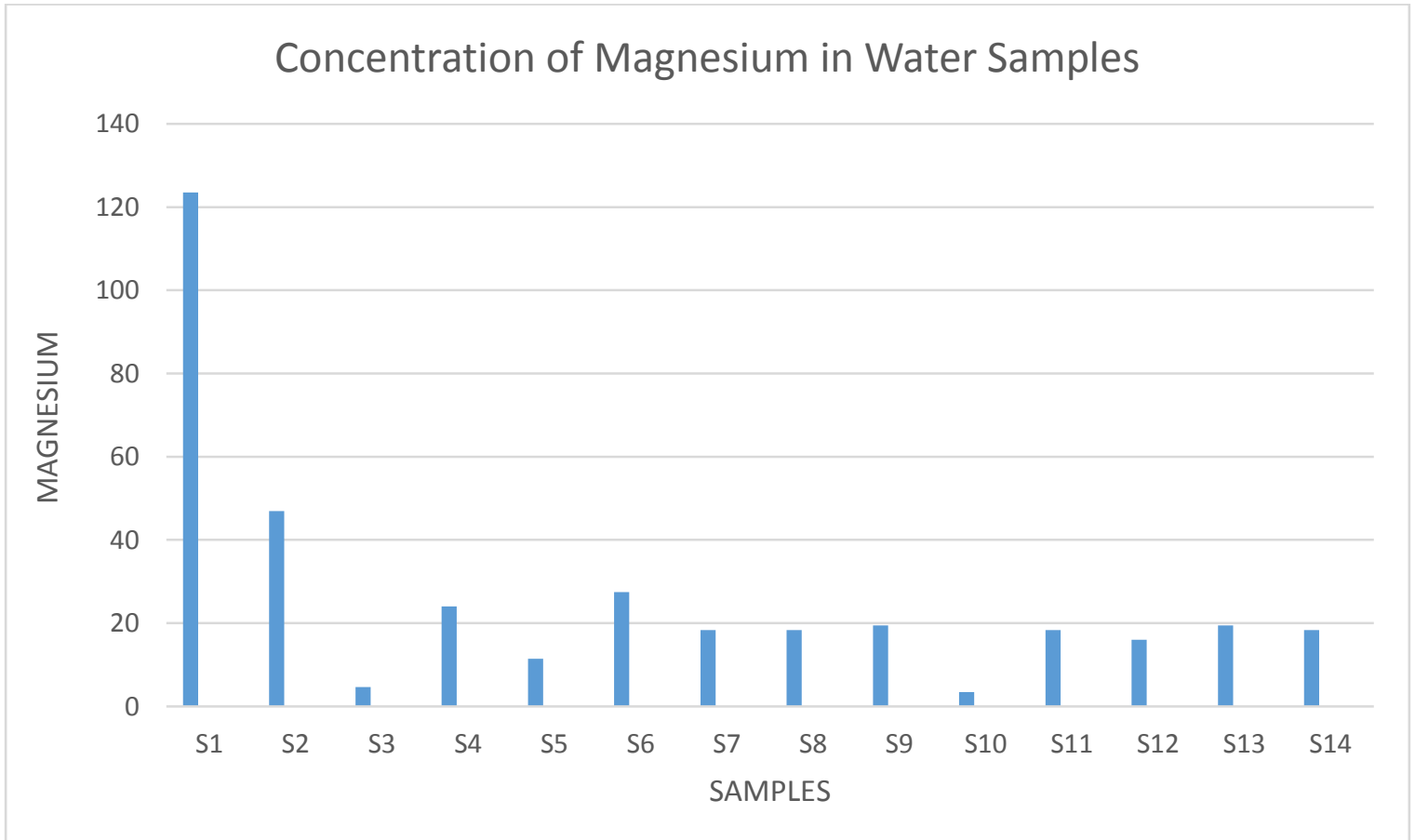

Figure 10: Chart showing magnesium in water samples 
International Journal of Advances in Scientific Research and Engineering (ijasre), Vol 6 (4), April -2020

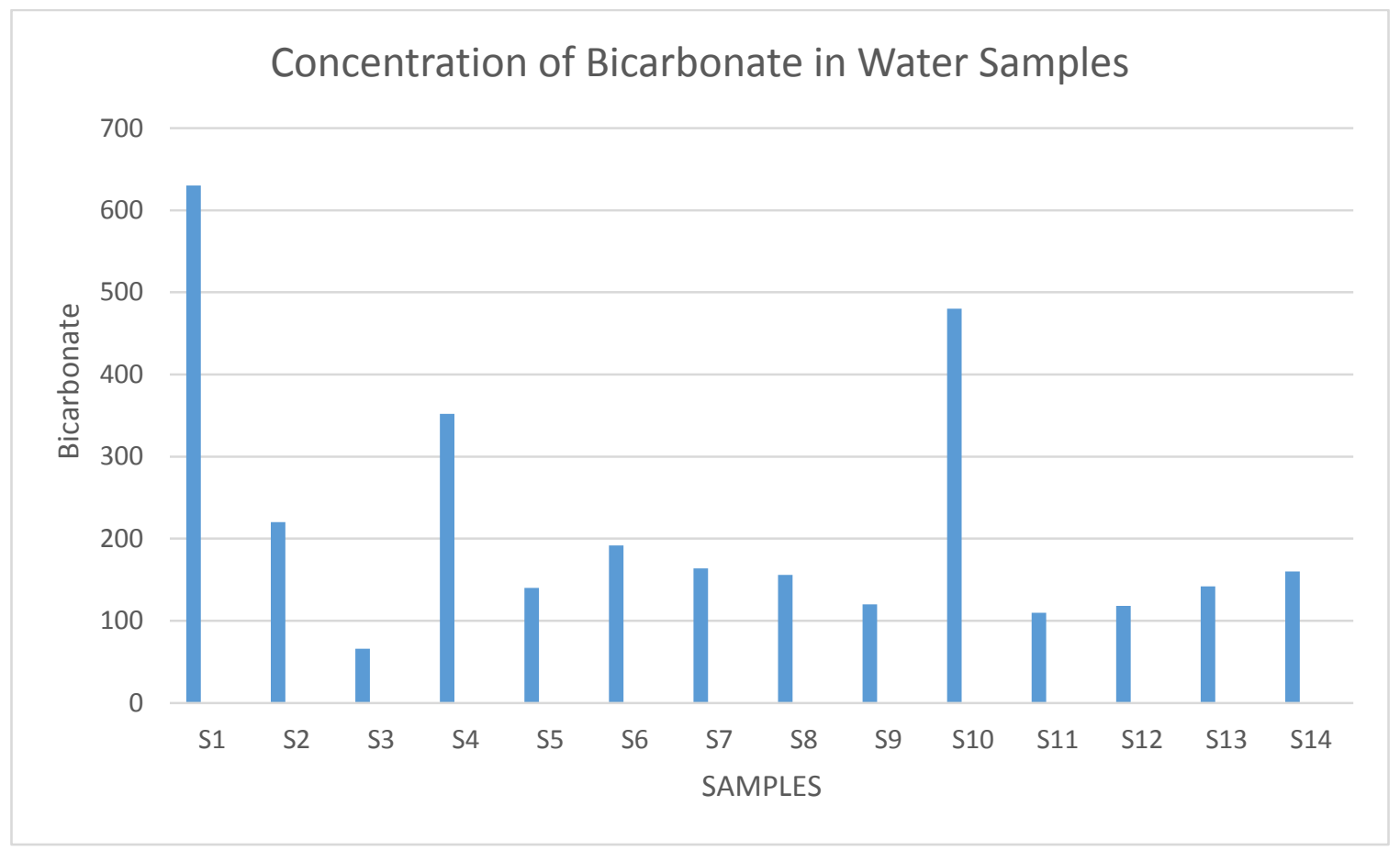

Figure 11: Chart showing concentration of bicarbonate in water samples

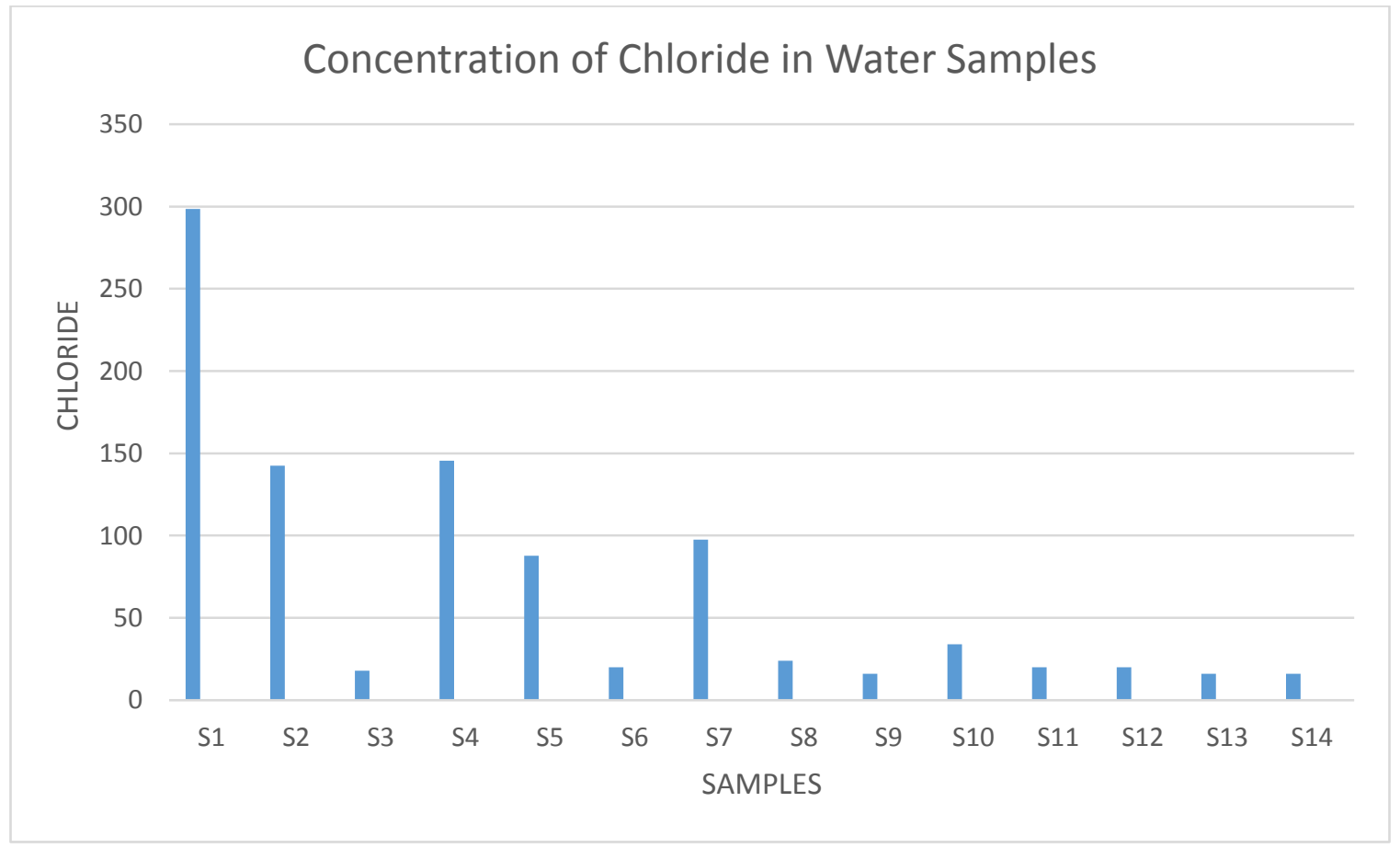

Figure 12: Chart showing concentration of chloride in the water samples 
International Journal of Advances in Scientific Research and Engineering (ijasre), Vol 6 (4), April -2020

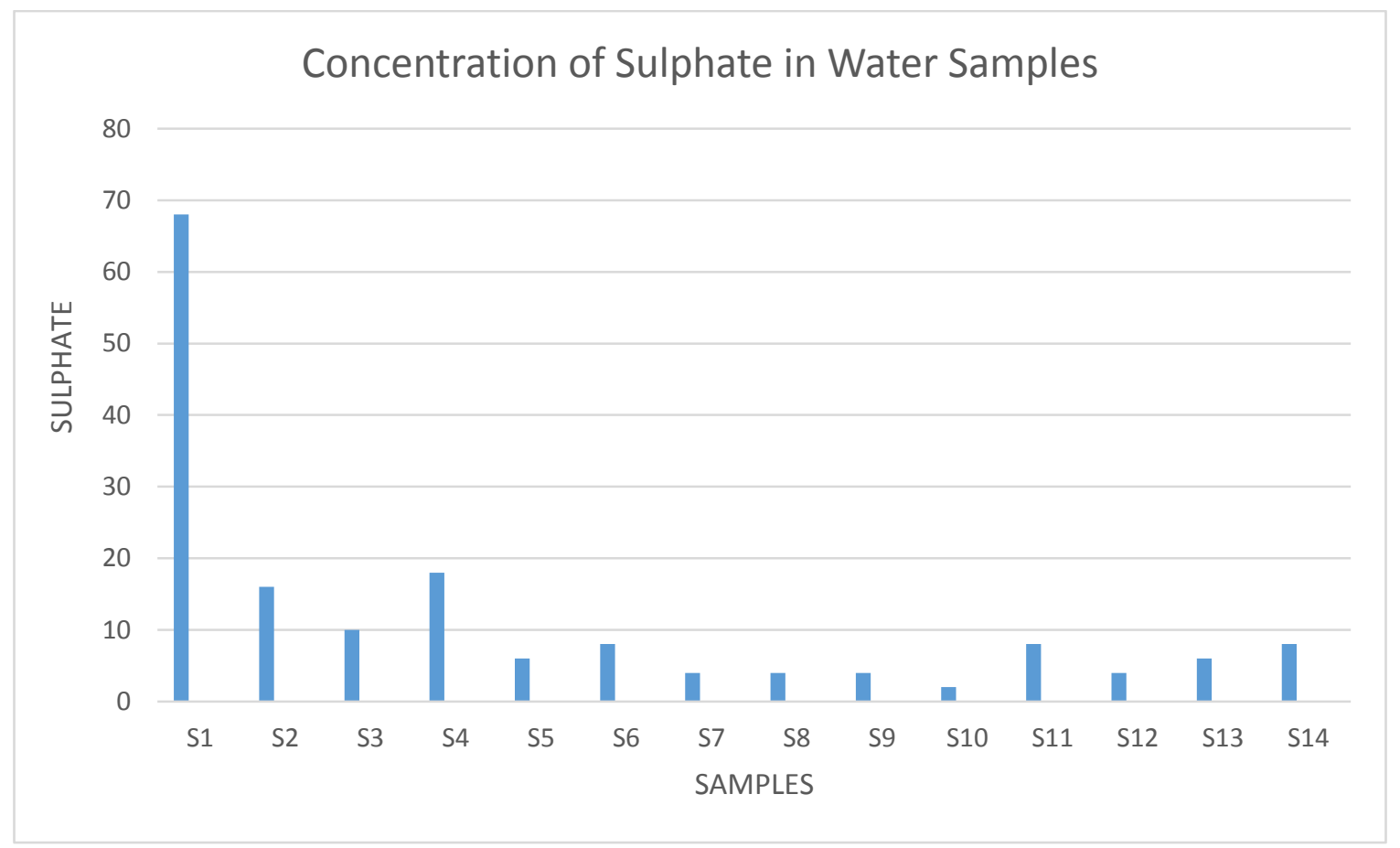

Figure 13: Chart showing concentration of sulphate in water samples

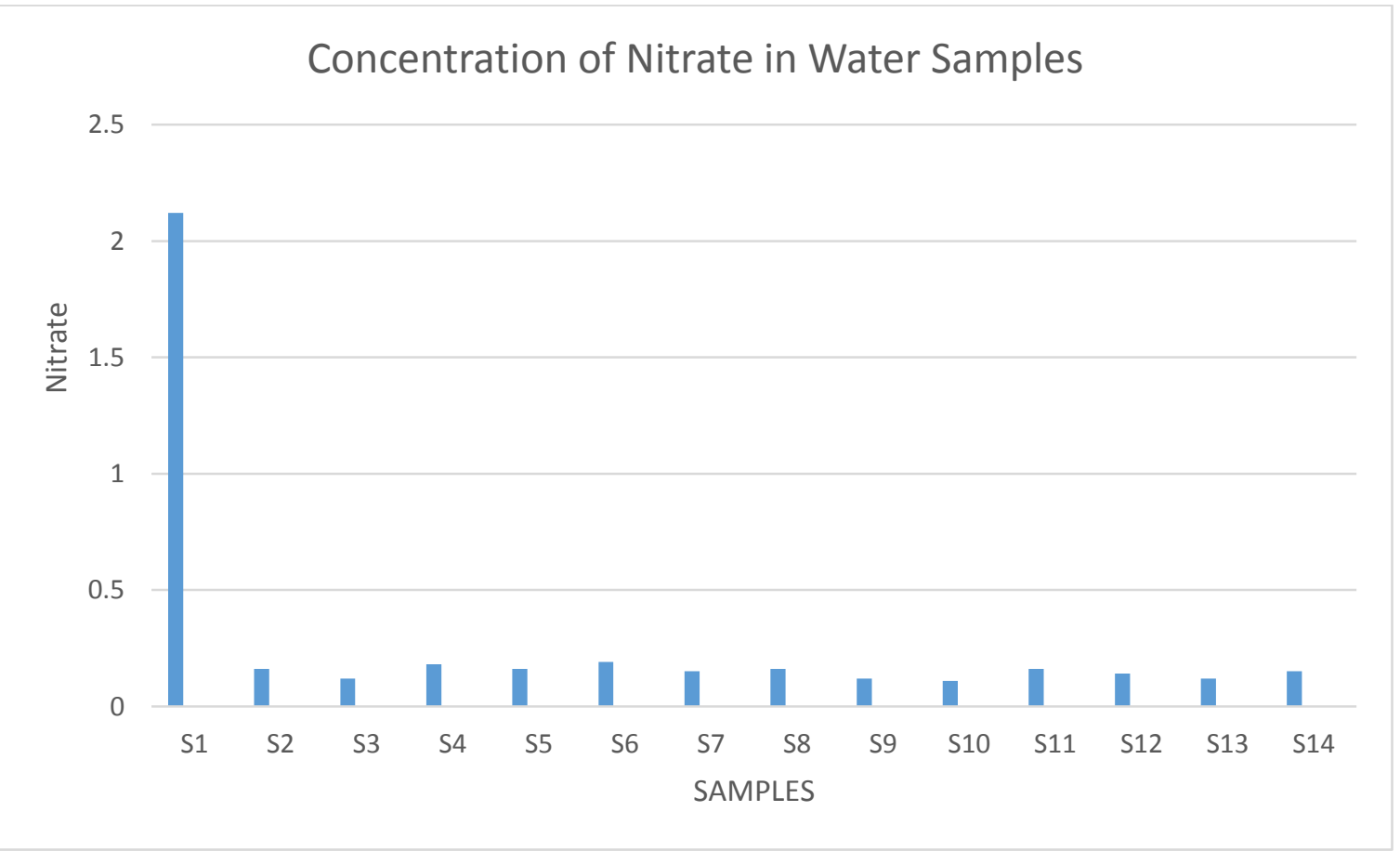

Figure 14: Chart showing concentration of Nitrate in water samples

\subsection{Principal component analysis}

The chemical results were subjected to Factor and Principal component analysis in order to determine the relationship between the variables [25], and correlate the dependency of one parameter on the other [26]. Result of the Factor analysis showed that $\mathrm{pH}$ 
International Journal of Advances in Scientific Research and Engineering (ijasre), Vol 6 (4), April -2020

negatively correlated with all the other parameters including the EC, the major cations and the major anions (Table 4). Aside $\mathrm{pH}$ all other parameters measured showed significant positive correlation.

Table 4: Correlation Matrix of Variables in the Groundwater Samples

Correlation Matrix

\begin{tabular}{|c|c|c|c|c|c|c|c|c|c|c|c|}
\hline & & pH & EC & Ca & $\mathrm{Na}$ & $\mathbf{K}$ & Mg & $\mathrm{HCO3}$ & $\mathrm{Cl}$ & SO4 & $\mathrm{NO3}$ \\
\hline \multirow{10}{*}{ Correlation } & pH & 1.000 & & & & & & & \multirow[b]{8}{*}{$\begin{array}{r}1.00 \\
0\end{array}$} & \multirow{10}{*}{$\begin{array}{r}1.000 \\
067\end{array}$} & \multirow[b]{10}{*}{1.000} \\
\hline & EC & -.258 & 1.000 & & & & & & & & \\
\hline & $\mathrm{Ca}$ & -.026 & .828 & 1.000 & & & & & & & \\
\hline & $\mathrm{Na}$ & -.297 & .924 & .643 & 1.000 & & & & & & \\
\hline & $\mathbf{K}$ & -.354 & .940 & .670 & .978 & 1.000 & & & & & \\
\hline & Mg & -.357 & .922 & .641 & .978 & .977 & 1.000 & & & & \\
\hline & $\mathrm{HCO}_{3}$ & -.109 & .783 & .648 & .755 & .683 & .688 & 1.000 & & & \\
\hline & Cl & -.445 & .950 & .775 & .871 & .903 & .866 & .748 & & & \\
\hline & $\mathrm{SO}_{4}$ & -.280 & .934 & .731 & .956 & .937 & .959 & .737 & .887 & & \\
\hline & $\mathrm{NO}_{3}$ & -.267 & .890 & .654 & .972 & .928 & .945 & .740 & .823 & & \\
\hline
\end{tabular}

The Principal component analysis showed that two principal components together accounted for $89.127 \%$ of the total variance in the data set, in which the first principal component explains $78.598 \%$ of the total variance, and the second Principal component explains $10.528 \%$ of the total variance.

The components were extracted into two factor loadings (Table 5), with factor 1 explaining $78.598 \%$ of the loading containing EC, $\mathrm{Ca}, \mathrm{Na}, \mathrm{K}, \mathrm{Mg}, \mathrm{HCO}_{3}, \mathrm{Cl}, \mathrm{SO}_{4}$ and $\mathrm{NO}_{3}$.

Table 5: Rotated Principal Component Analysis Matrix of Variables in the Groundwater Samples

\begin{tabular}{|c|c|c|c|}
\hline \multirow[t]{2}{*}{ Variables } & \multicolumn{2}{|c|}{ Principal Components } & \multirow[t]{2}{*}{ Communality } \\
\hline & 1 & 2 & \\
\hline pH & -.113 & -.961 & .936 \\
\hline EC & .971 & .142 & .962 \\
\hline $\mathbf{C a}$ & .835 & -.175 & .728 \\
\hline $\mathbf{N a}$ & .940 & .249 & .946 \\
\hline $\mathbf{K}$ & .922 & .306 & .945 \\
\hline Mg & .916 & .314 & .938 \\
\hline $\mathrm{HCO}_{3}$ & .835 & -.053 & .700 \\
\hline $\mathrm{Cl}$ & .895 & .319 & .902 \\
\hline $\mathrm{SO}_{4}$ & .953 & .203 & .948 \\
\hline $\mathrm{NO}_{3}$ & .929 & .209 & .906 \\
\hline \% of Variance & 78.598 & 10.528 & \\
\hline Cumulative \% of variance & 78.598 & 89.127 & \\
\hline
\end{tabular}

This factor is influenced by rock dominance process of weathering indicating dominance of rock - water interaction process in producing the major cations and anions in the water as indicated by the Gibb's diagram (Figure 15). Gibb's diagram can be used to categorize the functional sources of dissolved chemical constituents in groundwater into precipitation dominance, rock dominance, and evaporation dominance indicating control over the water chemistry [27]. Gibbs' diagram represent the ratios of $\mathrm{Na}+/(\mathrm{Na}++\mathrm{Ca} 2+)$ and $\mathrm{Cl}-+/(\mathrm{Cl}-+\mathrm{HCO}-)$ against TDS. 
International Journal of Advances in Scientific Research and Engineering (ijasre), Vol 6 (4), April -2020

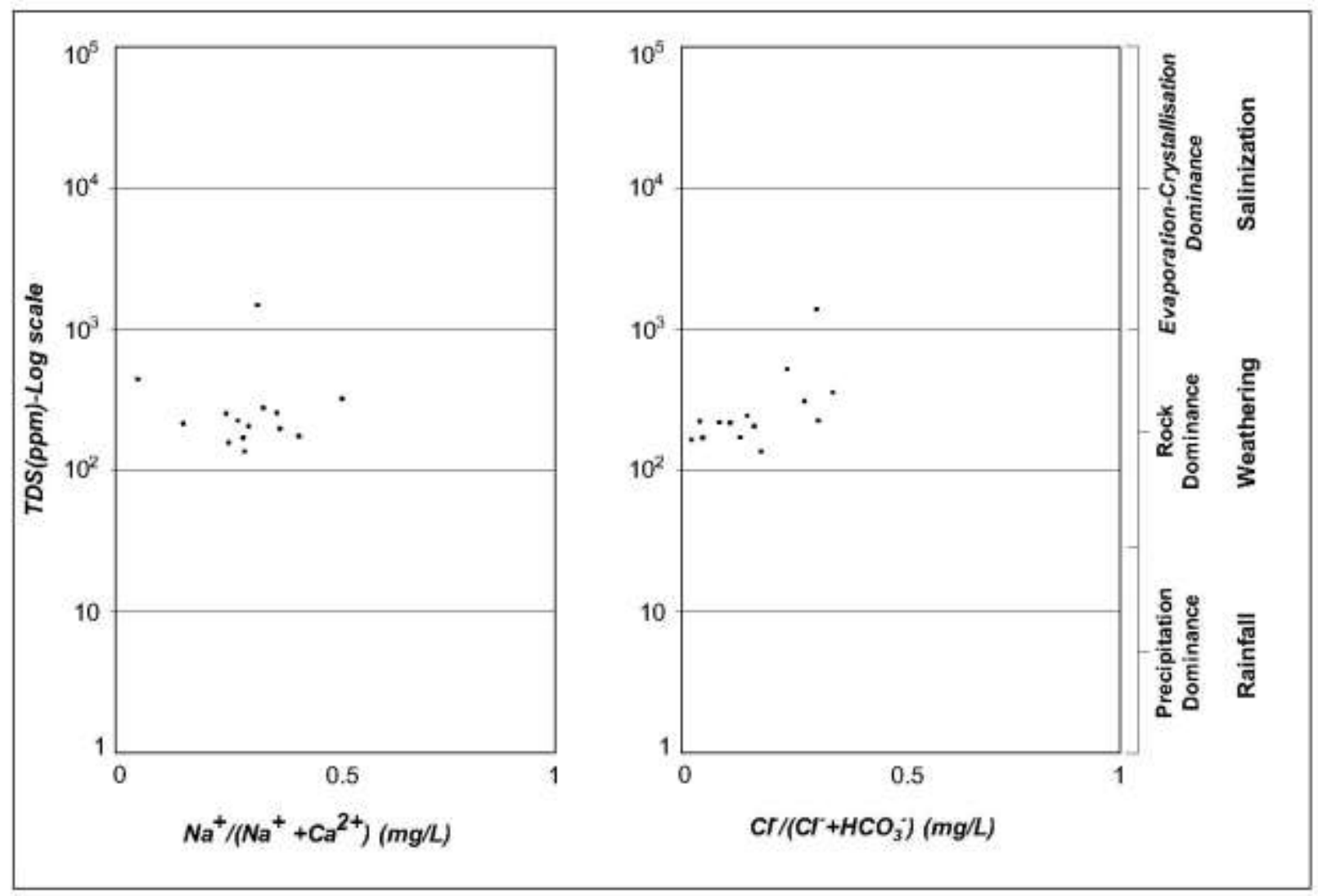

Figure 15: Gibbs diagram for the samples from Ajakanga and environs

\subsection{Water facies}

The Piper Trilinear diagram [28] is a convenient plot that can be employed in the classification of water into facies or types. Plot of the water samples on the Piper diagram indicated that two water facies exist in the area; $78.57 \%$ of the sampled waters were $\mathrm{CaHCO}_{3}$ water and include water from locations $1,3,4,6,8,9,10,11,12,13$ and 14 , while $21.43 \%$ of the waters were mixed waters of $\mathrm{CaMgCl}$, and include waters from location 2, 5 , and 7 (Figure 16). 


\section{Piper Diagram for the water samples}

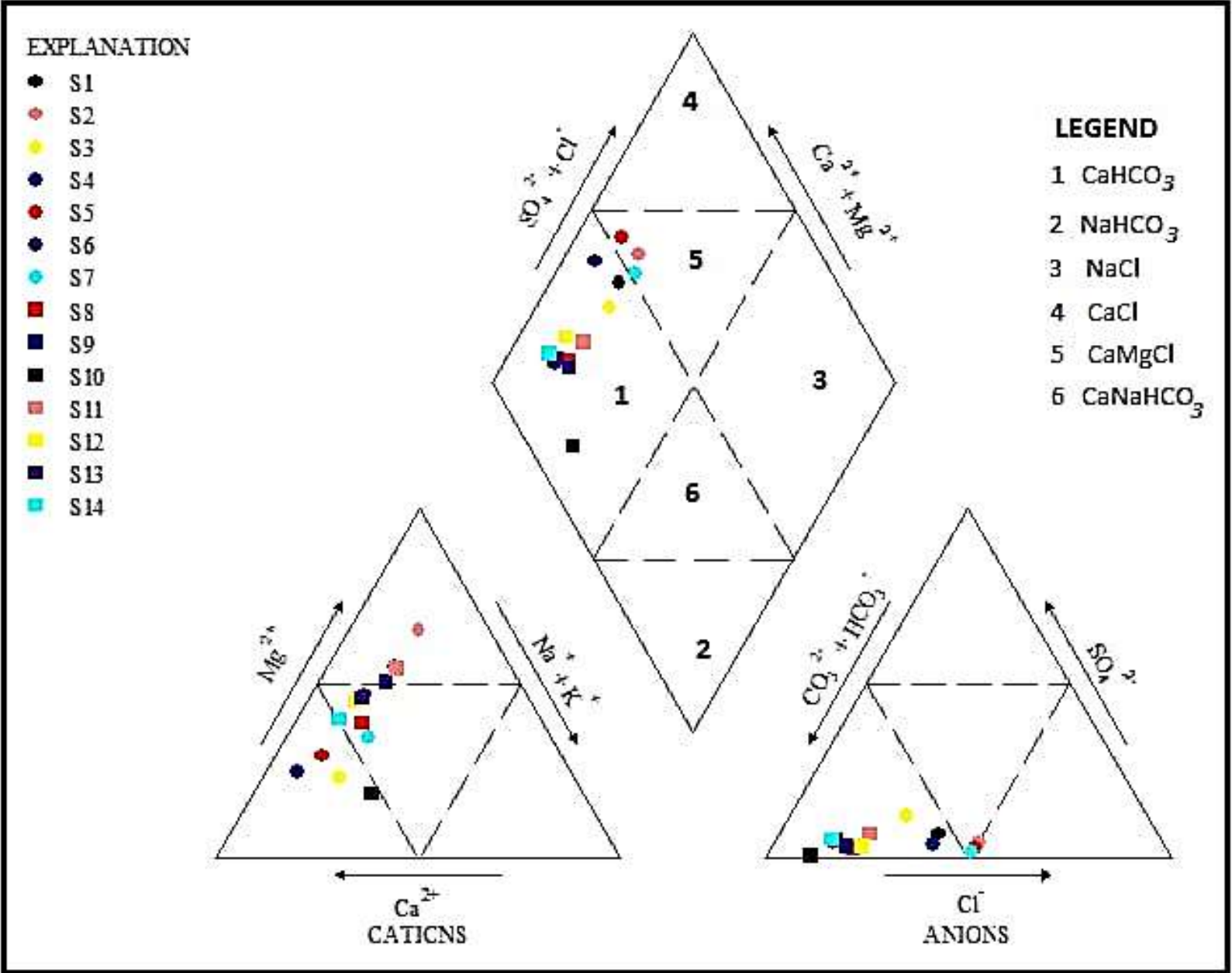

Figure 16: Water facies of Ajaganga and environs

\subsection{Mechanism controlling groundwater chemistry}

Scatter plots of major cations and anions in groundwater are commonly employed in order to determine their origin or source [29, 30, 31, 32]. Consequently, scatter plots of the major ions were carried out in order to determine the origin or sources contributing the major ions to the groundwater of Ajaganga and environs.

\subsubsection{Source of Sodium and Potassium}

\section{Na versus $\mathbf{C l}$}

A plot of $\mathrm{Na}$ versus $\mathrm{Cl}$ has been used to recognize the sources of salinity in groundwater environment. A plot of $\mathrm{Na} / \mathrm{Cl}$ above the equiline showed that $\mathrm{Na}$ is released from the weathering of silicate rocks [29, 33] due to rock-water interaction, while a plot below the equiline which indicate a dominance of $\mathrm{Cl}$ over $\mathrm{Na}$ may be as a result of Base Exchange phenomena or due to pollution by anthropogenic activities.

In the study area, the plot of $\mathrm{Na} / \mathrm{Cl}$ (Figure 17) showed that nine(9) of the fourteen sample plotted above the equiline indicating the dominance of $\mathrm{Na}$ over $\mathrm{Cl}$ signifying the preponderance of $\mathrm{Na}$ derived from the silicate weathering of the lithological units in the area. Also, the dominance of $\mathrm{HCO}_{3}$ over the other anions showed that the probable source of $\mathrm{Na}$ in the groundwater is silicate weathering [34]. This is as a result of the reaction of feldspar minerals with carbonic acid in the presence of water which produce $\mathrm{HCO}_{3}[31]$. 
International Journal of Advances in Scientific Research and Engineering (ijasre), Vol 6 (4), April -2020

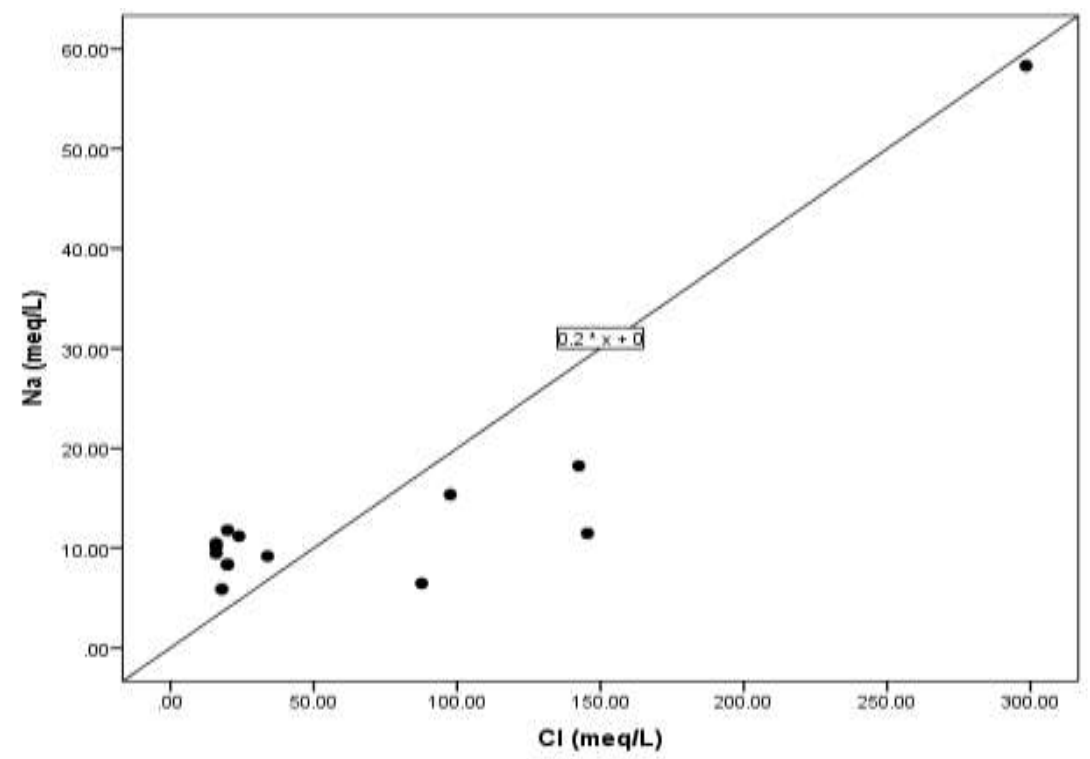

Figure 17: Plot of $\mathrm{Na}^{+}$against $\mathrm{Cl}^{-}$in the water samples of Ajaganga and environs

\section{$\mathrm{Na}+\mathrm{K}$ versus $\mathrm{Tz}$}

A plot of $\mathrm{Na}+\mathrm{K}$ versus $\mathrm{Tz}$ (total cations) below the equiline shows higher ratio of cation through silicate weathering [33]. A plot of $\mathrm{Na}+\mathrm{K} / \mathrm{Tz}$ of the water samples (Figure 18) showed that thirteen of the fourteen samples plotted below the equiline, showing dominance of total cation over $\mathrm{Na}+\mathrm{K}$ indicating weathering of the underlying silicate rocks as the major factor contributing the cations in the shallow underground water.

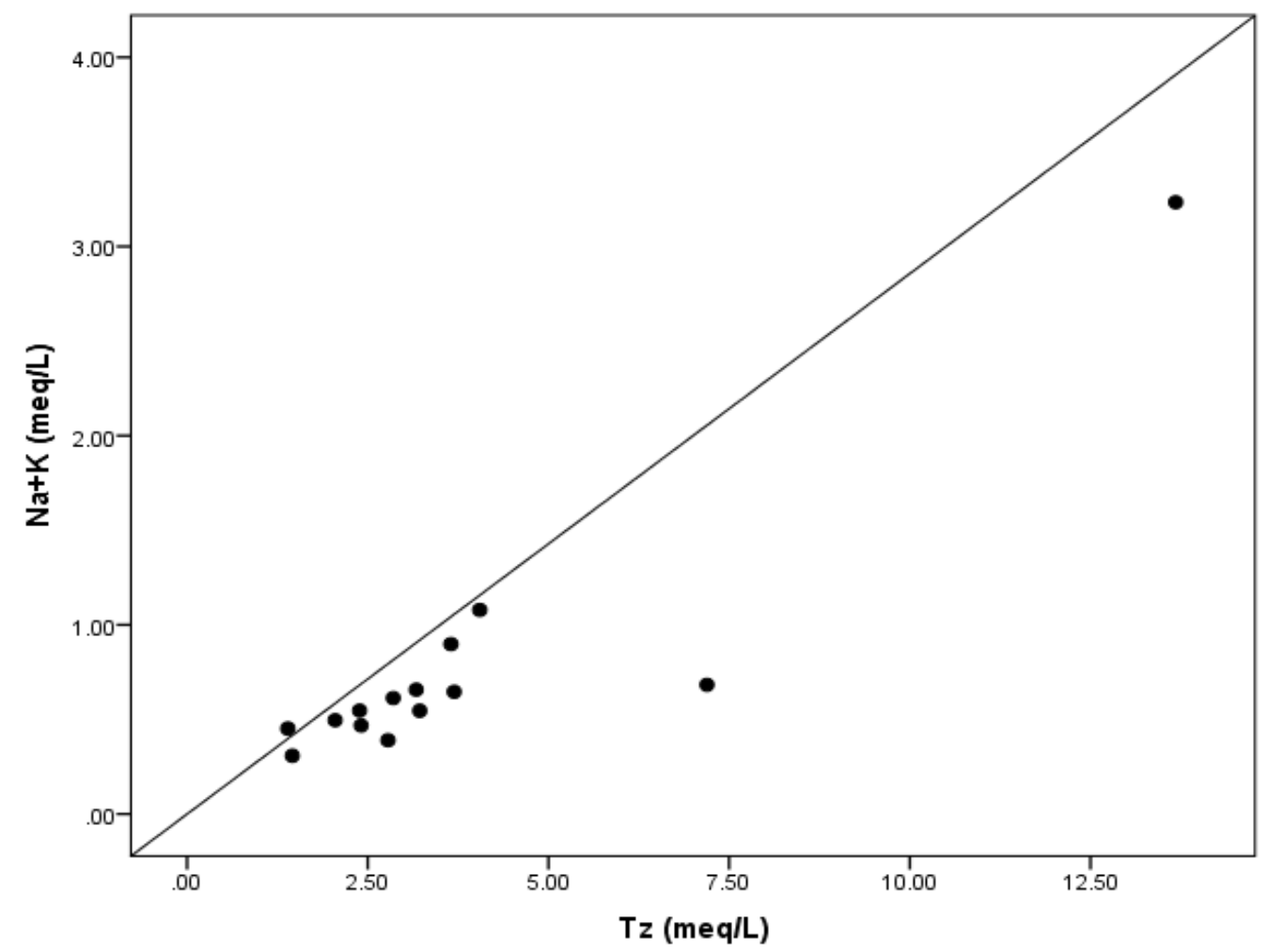

Figure 18: Plot of $\mathrm{Na}^{+}+\mathrm{K}^{+}$against $\mathrm{Tz}$ in the water samples of Ajaganga and environs 


\subsubsection{Source of Calcium and Magnesium}

\section{$\mathrm{Ca}+\mathrm{Mg}$ versus $\mathrm{HCO}_{3}$}

A plot of $\mathrm{Ca}+\mathrm{Mg}$ against $\mathrm{HCO}_{3}$ (Figure 19) showed that twelve of the fourteen water samples plotted above the equiline indicating the dominance of $\mathrm{Ca}+\mathrm{Mg}$ over $\mathrm{HCO}_{3}$. Excess calcium and magnesium is most likely derived from the weathering of silicate minerals such as plagioclase, pyroxene, amphiboles which are common in the basement rocks of the area.

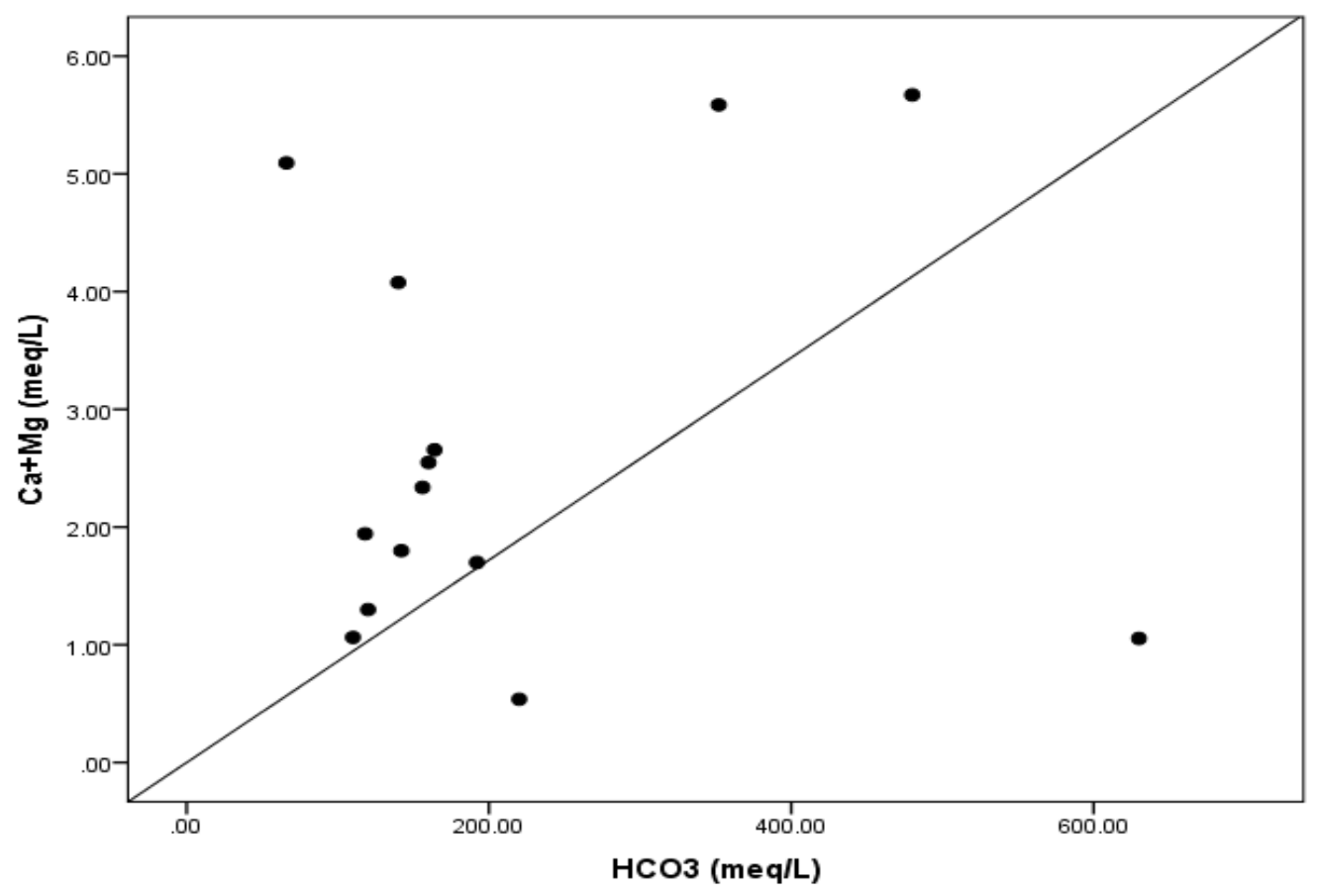

Figure 19: Plot of $\mathrm{Ca}^{2+}+\mathrm{Mg}^{2+}$ against $\mathrm{HCO}_{3}{ }^{-}$in the water samples of Ajaganga and environs

\section{$\mathrm{Ca}+\mathrm{Mg}$ versus $\mathrm{HCO}_{3}+\mathrm{SO}_{4}$}

A plot of $\mathrm{Ca}+\mathrm{Mg}$ against $\mathrm{HCO}_{3}+\mathrm{SO}_{4}$ (Figure 20) showed that twelve of the fourteen samples plotted above the equiline. This indicate a dominance of $\mathrm{Ca}+\mathrm{Mg}$ over $\mathrm{HCO}_{3}+\mathrm{SO}_{4}$ showing the process of silicate weathering in the study area.

The plot of $\mathrm{Ca}+\mathrm{Mg}$ versus $\mathrm{SO}_{4}+\mathrm{HCO}_{3}$ is a major indicator in the identification of ion exchange process. If ion exchange is responsible for the formation of the ions, the points tend to plot below the equiline due to an excess of $\mathrm{SO}_{4}+\mathrm{HCO}_{3}$. If reverse ion exchange is the process responsible, the points plot above the equiline due to excess of $\mathrm{Ca}+\mathrm{Mg}$ over $\mathrm{SO}_{4}+\mathrm{HCO}_{3}$.

The plot of $\mathrm{Ca}+\mathrm{Mg}$ versus $\mathrm{SO}_{4}+\mathrm{HCO}_{3}$ in the water samples of the study area showed that twelve of the fourteen samples plotted above the equiline indicating that reverse ion exchange process is responsible for the presence of the ions in the waters. This process causes $\mathrm{Na}^{+}$to replace $\mathrm{Ca}^{2+}+\mathrm{Mg}^{2+}$ in the aquifer matrix at favourable sites and the release of $\mathrm{Ca}^{2+}+\mathrm{Mg}^{2+}$ into the water. 
International Journal of Advances in Scientific Research and Engineering (ijasre), Vol 6 (4), April -2020

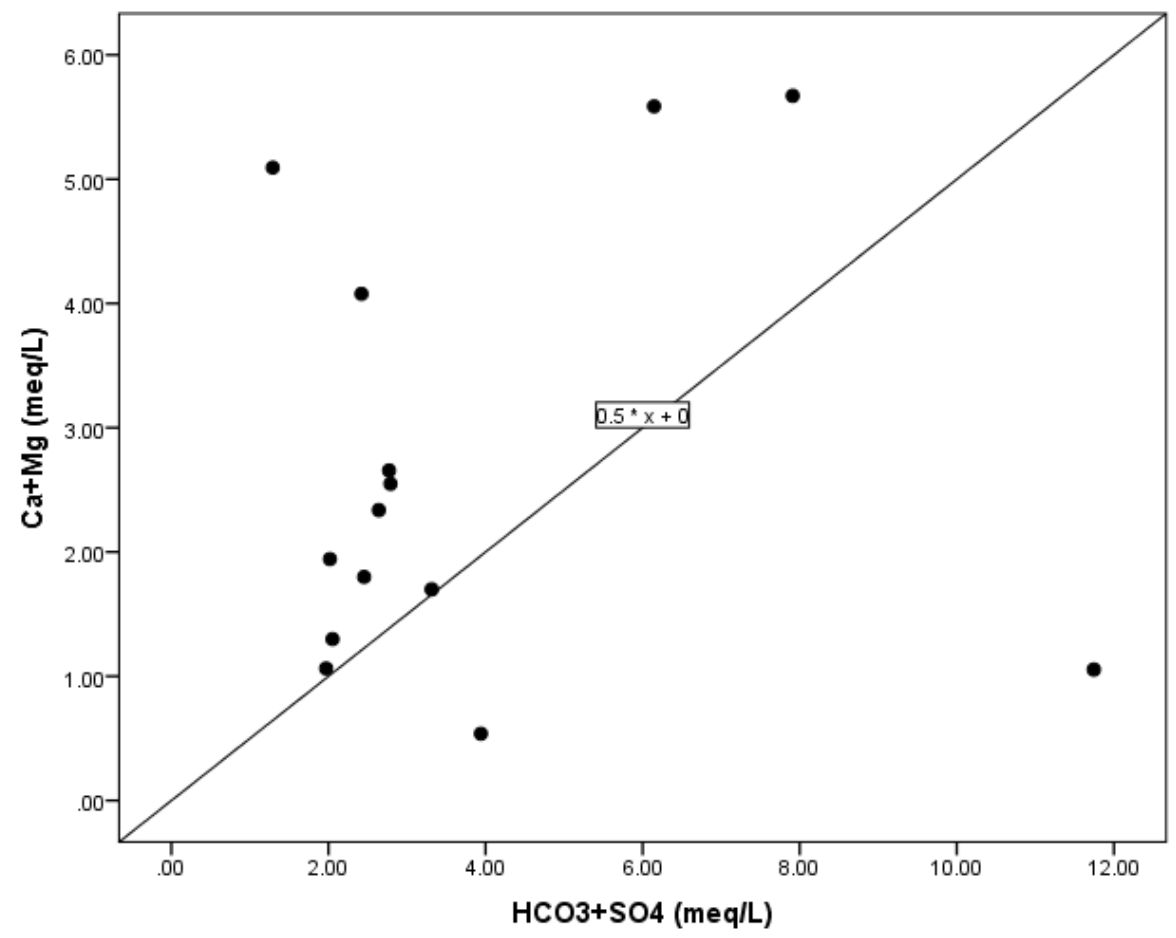

Figure 20: $\mathrm{Plot}$ of $\mathrm{Ca}^{2+}+\mathrm{Mg}^{2+}$ against $\mathrm{HCO}_{3}{ }^{-}+\mathrm{SO}_{4}{ }^{2-}$ in the water samples of Ajaganga and environs

\subsubsection{Bicarbonate, Chloride and Sulphate}

\section{$\mathrm{Cl}$ versus $\mathrm{HCO}_{3}$}

A scatter plot of $\mathrm{Cl}$ versus $\mathrm{HCO}_{3}$ (Figure 21) showed a dominance of $\mathrm{HCO}_{3}$ over $\mathrm{Cl}$. Generally, $\mathrm{HCO}_{3}$ is the dominant anion in the groundwater. $\mathrm{HCO}_{3}$ in groundwater is derived mainly from soil zone $\mathrm{CO}_{2}$ at the time of weathering of minerals of the parent rocks.

The soil zone in the subsurface environment contains elevated $\mathrm{CO}_{2}$ pressure due to the decay of organic matter and root respiration which in turn combines with rain water $\left(\mathrm{H}_{2} \mathrm{O}\right)$ to form $\mathrm{HCO}_{3}$ [35]. The reaction of feldspar minerals with carbonic acid in the presence of water is another possible source of $\mathrm{HCO}_{3}[31]$.

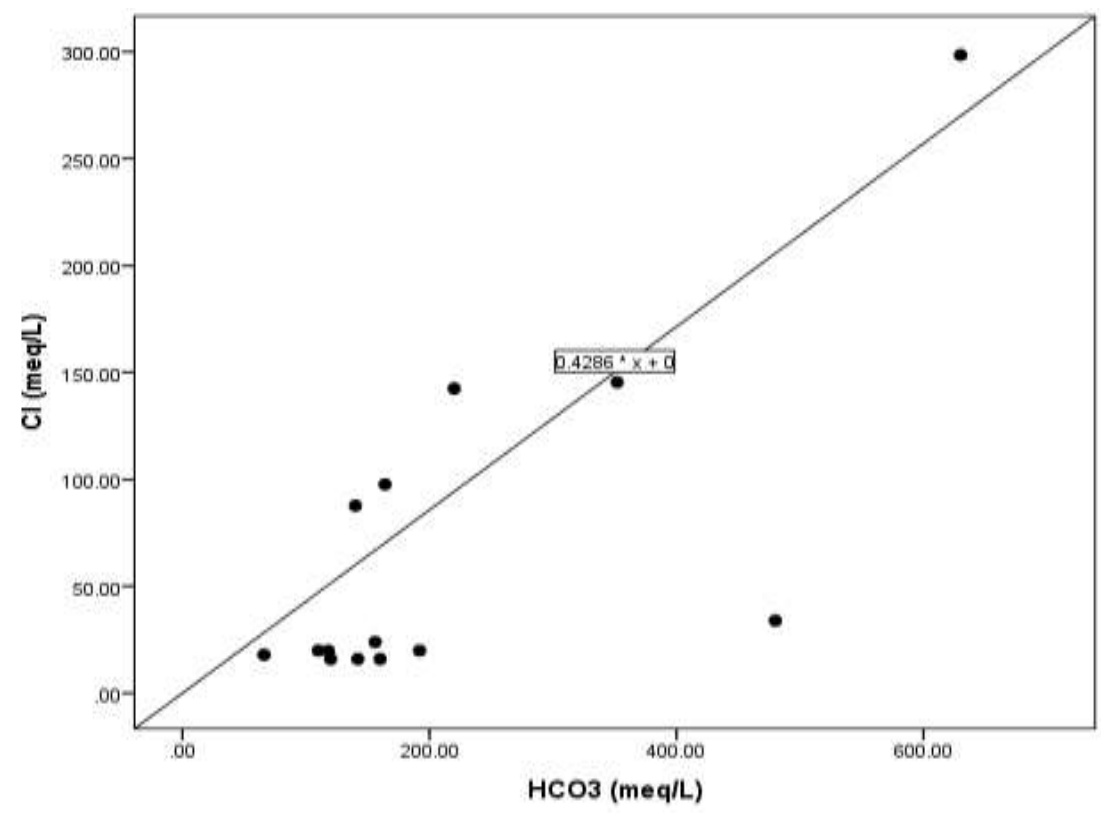

Figure 21: Plot of $\mathrm{Cl}^{-}$against $\mathrm{HCO}_{3}{ }^{-}$in the water samples of Ajaganga and environs 
International Journal of Advances in Scientific Research and Engineering (ijasre), Vol 6 (4), April -2020

\subsection{ION EXCHANGE PROCESSES}

\section{Chloro alkaline Indices $\left(\mathrm{CAI}_{1}\right.$ and $\left.\mathrm{CAI}_{2}\right)$}

The ion exchange process was determined using the formula formulated by [36]. This explains the ion exchange process between the groundwater and its surroundings during residence or travelling in the aquifer.

The Chloro alkaline Indices $\mathrm{CAI}_{1}$ and $\mathrm{CAI}_{2}$ (equations 1 and 2) is employed in determining the ion exchange process. Positive $\mathrm{CAI}$ indicates the exchange of $\mathrm{Na}$ and $\mathrm{K}$ from the water with $\mathrm{Ca}$ and $\mathrm{Mg}$ of the rocks, with the subsequent release of $\mathrm{Ca}$ and $\mathrm{Mg}$ into the waters. Negative CAI indicate the exchange of $\mathrm{Ca}$ and $\mathrm{Mg}$ of the water with $\mathrm{Na}$ and $\mathrm{K}$ of the rock (Nagaruju et al., 2006; Celik et al., 2008)[37, 38].

$\mathrm{CAI}_{1}=(\mathrm{Cl}-(\mathrm{Na}+\mathrm{K})) / \mathrm{Cl}$

$\mathrm{CAI}_{2}=(\mathrm{Cl}-(\mathrm{Na}+\mathrm{K})) / \mathrm{SO}_{4}+\mathrm{HCO}_{3}+\mathrm{CO}_{3}+\mathrm{NO}_{3}$

The result of both $\mathrm{CAI}_{1}$ and $\mathrm{CAI}_{2}$ (Table 6) showed that ten samples representing $71.43 \%$ of the population sampled have positive CAI, while $28.57 \%$ have negative CAI. These results indicated that reverse ion exchange process is responsible for the presence of the major ion in ten $(71.43 \%$ ) of the locations, indicating an exchange of $\mathrm{Ca}$ and $\mathrm{Mg}$ of the host rocks with $\mathrm{Na}$ and $\mathrm{K}$ from the water. Consequently, weathering and release of the constituent components $\mathrm{Ca}$ and $\mathrm{Mg}$ of the underlying basement rocks in exchange for the $\mathrm{Na}$ and $\mathrm{K}$ of the water is the main process responsible for the major ions in the groundwater.

Table 6: results of the Chloro Alkaline Indices for the groundwater of Ajakanga and environs

\begin{tabular}{|l|l|l|}
\hline Sample location & $\mathbf{C A I}_{\mathbf{1}}(\mathbf{m e q} / \mathbf{L})$ & $\mathbf{C A I}_{\mathbf{2}}(\mathbf{m e q} / \mathbf{L})$ \\
\hline $\mathbf{1}$ & 0.621 & 0.449 \\
\hline $\mathbf{2}$ & 0.735 & 0.758 \\
\hline $\mathbf{3}$ & 0.399 & 0.158 \\
\hline $\mathbf{4}$ & 0.836 & 0.565 \\
\hline $\mathbf{5}$ & 0.844 & 0.873 \\
\hline $\mathbf{6}$ & -0.135 & -0.023 \\
\hline $\mathbf{7}$ & 0.678 & 0.682 \\
\hline $\mathbf{8}$ & 0.039 & 0.010 \\
\hline $\mathbf{9}$ & -0.200 & -0.044 \\
\hline $\mathbf{1 0}$ & 0.533 & 0.065 \\
\hline $\mathbf{1 1}$ & 0.129 & 0.037 \\
\hline $\mathbf{1 2}$ & 0.178 & 0.050 \\
\hline $\mathbf{1 3}$ & -0.345 & -0.064 \\
\hline $\mathbf{1 4}$ & -0.198 & -0.032 \\
\hline
\end{tabular}

\section{$\mathrm{Ca} / \mathrm{HCO}_{3}$}

Low molar ratio of $\mathrm{Ca} / \mathrm{HCO} 3(<0.5)$ indicate exchange of $\mathrm{Ca}$ and $\mathrm{Mg}$ in water by $\mathrm{Na}$ bound in clay, while high ratio (>0.5) suggest other sources for $\mathrm{Ca}$ and $\mathrm{Mg}$, such as reverse ion exchange [39].

In the study area, eleven (11) of the fourteen (14) water samples have $\mathrm{Ca} / \mathrm{HCO}_{3}$ ratio greater than 0.50 (Table 7), indicated that reverse ion exchange process is responsible for the dominance of $\mathrm{Ca}$ and $\mathrm{Mg}$ ions in the waters.

Table 7: Ratio of $\mathrm{Ca} / \mathrm{HCO}_{3}$ in the water samples of Ajakanga and environs

\begin{tabular}{|l|l|}
\hline Sample location & $\mathbf{C a} / \mathbf{H C O}_{\mathbf{3}}(\mathbf{m e q} / \mathbf{L})$ \\
\hline $\mathbf{1}$ & 0.52 \\
\hline $\mathbf{2}$ & 0.29 \\
\hline $\mathbf{3}$ & 0.89 \\
\hline $\mathbf{4}$ & 0.96 \\
\hline $\mathbf{5}$ & 0.84 \\
\hline $\mathbf{6}$ & 0.61 \\
\hline $\mathbf{7}$ & 0.74 \\
\hline
\end{tabular}




\begin{tabular}{|l|l|}
\hline $\mathbf{8}$ & 0.69 \\
\hline $\mathbf{9}$ & 0.53 \\
\hline $\mathbf{1 0}$ & 0.10 \\
\hline $\mathbf{1 1}$ & 0.44 \\
\hline $\mathbf{1 2}$ & 0.66 \\
\hline $\mathbf{1 3}$ & 0.62 \\
\hline $\mathbf{1 4}$ & 0.73 \\
\hline
\end{tabular}

\subsection{CONCLUSIONS}

Generally, the shallow groundwater of Ajakanga area is fit for drinking purposes based on the WHO (2008) chemical parameter standards for drinking water, however as a result of high values of $\mathrm{Cl}^{-}$, the water from location 1 is unfit for drinking purposes. Also, the groundwater can safely be used for irrigation purposes.

The Principal Component analysis divided the dataset into two components with factor 1 containing $\mathrm{EC}, \mathrm{Ca}^{2+}, \mathrm{Na}^{+}, \mathrm{K}^{+}, \mathrm{Mg}^{2+}, \mathrm{HCO}_{3}^{-}$, $\mathrm{Cl}-, \mathrm{SO}_{4}{ }^{2-}$ and $\mathrm{NO}_{3}{ }^{-}$, excepting only $\mathrm{pH}$. This result indicate a significant relationship in the source of these components of the groundwater.

The plot of Gibbs diagram showed that the major ions in the groundwater are sourced mainly from the underlying basement rocks which are rich in these components as a result of weathering. Also, the scatter plot of major ions, generally, indicated the weathering of the underlying basement rocks as the source of the major cations in the underground water.

The Piper Trilinear diagram indicated two groundwater facies in the area. $\mathrm{CaHCO}_{3}$ water being dominant, while $\mathrm{CaMgHCO}_{3}$ water is subordinate. The use of Chloro Alkaline Indices confirmed that the major ions entered the groundwater of Ajakanga area as a result of reverse ion exchange process.

\section{REFERENCES}

[1]. Redwan, M., Abdel, T. and Moneim, A.A. (2015). Factors controlling groundwater hydrogeochemistry in the area west of tahta, Sohag, Upper Egypt. Journal of African Earth Sciences

[2]. Sakram, G. and Adimalla, N. (2018).Hydrogeochemical characterization and assessment of water suitability for drinking and irrigation in crystalline rocks of Mothkur region, Telagane state, south India, Applied Water Science, 8: 143.

[3]. Saravanan, K., Srinivasamoorthy, K., Prakash, R., Gopinath, S., Suma, C.S. (2015). An evaluation of Hydrogeochemistry of Groundwater in Upper Vellar Sub-basin using Mineral stability and solute Transport Modelling. Aquatic Procedia, 4, 1119-1125.

[4]. He, J., Ma, J., Zhao, W., Sun, S. (2015). Groundwater evolution and recharge determination of the Quaternary aquifer in the Shule River basin, Northwest China. Hydrogeol. J. 23: 1745-1759.

[5]. Rao, N.S. (2006). Groundwater potential index in a crystalline terrain using remote sensing data. Environ. Geol. 50: 1067-1076.

[6]. Fashae, O.A. (2014). .Delineation of Groundwater potential zones in the crystalline basement terrain of SW-Nigeria: an integrated GIS and remote sensing approach. Applied Water Science 4, 19-38.

[7]. Belkiri, L. and Mouni, L. (2012).Geochemical Modelling of groundwater in the El Eulma area, Algeria. Desalination and Water Treatment, Vol. 51, no. 7-9, pp. 1468-1476.

[8]. Fisher, R.S. and Mulican, W.F. (1997)..Hydrochemical evolution of sodium-sulfate and sodium-chloride groundwater beneath the Northern Chihuahuan desert,Trans Pecos, Rexas, USA. Hydrogeology Journal (10) 455-474.

[9]. Vidal, M. J., Melgar, A. Lopez and Santoalla, M.C. (2000).Spatial and temporal hydrochemical changes in groundwater under the contaminating effects of fertilizers and wastewater Journal of Environmental Management 60(3): 215-225.

[10]. Dindane, K. L., Hsissou Bouchaou, Y. and Krimissa, M. (2003). Hydrochemical and isotopic characteristics of groundwater in the Souss Upstream Basin, southwestern Morocco. Journal of African Earth Sciences 38(4): 315-327.

[11]. Iwatsuki, T. Furue, R. Mie, H. Ioka, S. and Mizuno, T. (2005).Hydrochemical baseline conditions of groundwater at Mizunami underground research laboratory (Miu). Applied Geochemistry 20: 2283-2302.

[12]. Cloutier, V. Lefebvre, R. M. Savard, M. Bourque, E. and Therrien, R. (2006). Hydrogeochemistry and groundwater origin of the Basses Laurentides sedimentary rock aquifer system, St Lawrence Lowlands, Quebec. Canada Hydrogeology Journal. 14(4): 573-590. [13]. World Health Organization (WHO), (2008). Guidelines for drinking water quality. Geneva.

[14]. Federal republic of Nigeria Official Gazette. Legal Notice on Publication of 2006 Census. Final Results.

[15]. Filani, M.O. and Akintola, F.O. (1982). Ibadan Region. University of Ibadan, Ibadan. 
International Journal of Advances in Scientific Research and Engineering (ijasre), Vol 6 (4), April -2020

[16]. Grant, N.K. (1970). Geochemistry of Precambrian rocks from Ibadan, southwestern Nigeria. Earth and Planet Science, Lett., 10, 29-38.

[17]. Jones, H.A. and Hockey, R.D. (1964). The geology of part of southwestern Nigeria. Bulletin of the Geological Survey of Nigeria, 31, 101pp.

[18]. Rahaman, M.A. (1976). Review of the basement geology of south-western Nigeria. In: Geology of Nigeria Kogbe, C.A. (ed.), Elizabethan Press: Lagos.

[19]. Dada, S.S. (2006). Proterozoic Evolution of Nigeria. The Basement complex of Nigeria and its mineral resources (A tribute to Prof. M.A.O. Rahaman). Akin Jinad and Co. Ibadan, 29-44.

[20]. Adelana,S.M.A., Olasehinde, P.I., Bale, R.B. Vrbka, P. Edet, A.E. Goni, I.B. (2008). An overview of the geology and hydrogeology of Nigeria. Applied groundwater studies in Africa.

[21]. Oteze, G.E. (1983). Groundwater levels and ground movements. In: Ola, S.A. (ed.), Tropical soils of Nigeria in engineering practice, Balkema, Rotterdam, the Netherlands, 39-58.

[22]. Davis, S.N. and DeWiest, R.J.M. (1966). Hydrogeology. New York: Wiley.

[23]. Dufur, C.N. and Becker, E. (1964). Public water supplies of the 100 largest cities in the US. Geological survey water supply paper 1812: 364.

[24]. Groeneveld, R.A. and Meeden, G. (1984). Measuring skewness and Kurtosis. J Ro. Stat. Soc. Series D (The Statistician), 33: 391-399.

[25]. Anandakumar, S., Subramani, T., Elango, L. (2009). Major ion groundwater chemistry of lower bahvani river basin, Tamil Nadu, India J. Appl. Geochem. 11(1), 92 - 101.

[26]. Sharma, P., Sharma, H.P. (2011). Groundwater quality assessment of Pachim Nalbari block of Nabari district Assam based on major ion chemistry. Int. J. ChemTech res. 3(4), 1914-1917.

[27]. Gibbs, R.J. 1970. Mechanisms controlling world's water chemistry. Science 170: 1088-1090.

[28]. Piper, A.M. 1944. A graphical procedure in the geochemical interpretation of water analysis. Trans. Am. Geophys. Union 25, 914-928.

[29]. Meybeck, M. 1987. Global chemical weathering of surficial rocks estimated from river dissolved loads. Am. J. Sci. 287, 401428.

[30]. Katz, B.G., Coplen, T.B., Bullen, T.D., Davis, J.H. (1998). Uses of chemical and isotopic tracers to characterize the interaction between groundwater and surface water in mantle karst. Groundwater 35 (6), 1014-1028.

[31]. Elango, L., Rannan, R., Senthil, K.M. (2003). Major ion chemistry and identification of hydrogeochemical processes of groundwater in a part of Kancheepuram district, Tamil nadu, India. Journal of environmental geosciences (10): 157-166.

[32]. Berhe, B.A., Celik, M., Dokuz, U.E. (2014). Determination of aquifer properties of the Kutahya plain from pumping and recovery test data. In: 67th Geological Congress of Turkey, Ankara, pp. 324-325.

[33]. Stallard, R.F. and Edmond, J.M. (1983). Geochemistry of the Amazon, the influence of geology and weathering environment of the dissolved load. Journal of Geophysical research (88): 9671-9688

[34]. Rogers, R.J. (1989). Geochemical comparison of groundwater in areas of New England, New York, and Pennsylvania. Groundwater (27): 690-720.

[35]. Subba Rao, N. and Surya Rao, P. (2010). Major ion chemistry of groundwater in a river basin.

[36]. Schoeller, H. (1967). Qualitative evaluation of groundwater resources. In: Methods and Techniques of Groundwater Investigations and Development UNESCO Water Resources Series, 33, 44 - 52.

[37]. Nagaraju, A., Suresh, S., Killham, K., Hudson, E.K. (2006). Hydrogeochemistry of waters of mangampeta Pradesh, India. Turk. J. Eng. Env. Sci. 30, 203-219.

[38]. Celik, M., Unsal, N., Tufenkci, O.O., Bolat, S. (2008). Assessment of water quality of the lake Seyfe basin, Kirsehir, Turkey. Environ. Geol. 55, 559-569.

[39]. Kumar, P.J.S. (2013). Interpretation of groundwater chemistry using piper and chadha's diagrams: A comparative study from Perambalur Taluk. Elixir, geosci., 54: 12208-12211. 